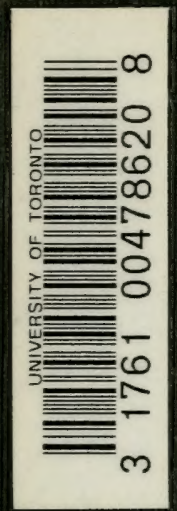



Digitized by the Internet Archive in 2008 with funding from Microsoft Corporation 

Religious Tract Society, 56, Paternoster Rono.

\section{THE MONTHLY VOLUME,}

EACH BOOK COMPLETE IN ITSELF, OCCASIONALLY ILLUSTRATED WITH ENGRAVINGS, AND CONTAINING ONE HUNDRED AND NINETY-TWO PAGES, IN A GOOD, BOLD TYPE.

SIXPENCE, IN FANCY PAPER COVERS.

TENPENCE, IN CLOTH BOARDS, GILT EDGES.

"I never wanted articles on religious subjects half so much as articles on common subjects, written with a decidedly Christian tone."-DR. ARNOLD.

The Committee of the Religious Tract Society have resolved to publish a volume every month, adapted to the new development and growing intelligence of the times. This series, with the exception of a few reprints, will be Original; from the pens of authors of ability in their respective departments in literature and science:-SCRIPTURAL; in the principles in which they are written : -Popular ; in their style ; so that instead of being limited to one class of the community, they may be generally acceptable:-PortaBLE; that they may serve as "hand-books" abroad and at home : -and Economical; the twelve volumes of a year costing less than three half-pence per week. Thus while the MONTHLY SERIES will be fully adapted to the educated FAmilies of our land, to Day and Sunday Schools and to the Libraries of mechanics and others, they will supply interesting and valuable reading to a large number of the people, who can only spare time enough for the perusal of a small volume, and whose means will not allow of a more costly purchase. 
1. THE LIFE OF JULIUS CASAR.

2. GLIMPSES OF THE DARK AGES.

3. WILD FLOWERS OF THE YEAR.

4. JAMAICA, ENSLAVED AND FREE.

5. OUR SONG BIRDs. By W. Martin, Esq.

6. SOLAR SYSTEM. Part I. By Dr. Dick.

7. THE TASK AND OTHER POEMS. By WM, COWPER.

8. SKETCHES OF THE WALDENSES.

9. SOLAR SYSTEM. Part II. By Dr. Dick.

10. LIFE OF LUTHER.

11. BLIGHTS of the WhEAT. By the Rev. E. Sidney, M.A. 12. ANCIENT JERUSALEM, By Dr. Kiтto.

13. PHILOSOPHY OF THE PLAN OF SALVATION.

14. MAN, IN HIS PHYSICAL, INTELLECTUAL, SOCIAL, AND MORAL RELATIONS. By W. NEWNham, Esq. 15. MODERN JERUSALEM. By Dr. KitTo.

16. LIFE OF CYRUS.

17. GARDEN FLOWERS OF THE YEAR.

18. DAWN OF MODERN CIVILIZATION.

19. LIFE OF LADY RUSSELL.

20. OUR DOMESTIC FOWLS. By W. Martin, Esq.

21. COWPER'S TRUTH, AND OTHER POEMS.

22. LIFE OF MOHAMMED.

23. SKETCHES OF THE FRENCH REVOLUTION.

24. THE CAVES OF THE EARTH.

25. EMINENT MEDICAL MEN.

26. LIFE OF MARTIN BOOS.

27. SELF-IMPROVEMENT.

28. COMPARISONS OF STRUCTURE IN ANIMALS.

29. PROTESTANTISM IN FRANCE. Part I.

30. MAGIC, PRETENDED MIRACLES, etc.

31. THE ATMOSPHERE AND ITS PHENOMENA. By Dr. DICK.

32. SCHOOLS OF ANCIENT PHILOSOPHY.

33. THE LIFE OF CRANMER.

34. THE ORIGIN AND PROGRESS OF LANGUAGE.

35. OUR ENGLISH BIBLE.

36. THE TAHTAR TRIBES. By Dr. KitTo.

37. LIFE OF NAPOLEON BONAPARTE.

38. PROTESTANTISM IN FRANCE. Part IT.

39. THE ARCTIC REGIONS, By Captain Scoresby.

40. THE COURT OF PERSIA. By Dr. KitTo.

4l. THE NORTHERN WHALE-FISHERY. By CAPTAIN SCORESBY.

42. THE CRUSADES.

43. LIFE OF JOHN KASPAR LAVATER.

44. LIFE'S LAST HOURS; or, THE FINAL TESTIMONY.

45. THE PEOPLE OF PERSIA. By Dr. KitTo.

46. LIFE OF ALFRED THE GREAT.

47. PLANTS AND TREES OF SCRIPTURE.

Other Volumes in preparation. 


\section{BRITISH}

FISH AND FISHERIES. 



\section{BR I T IS H}

\section{FISH AND FISHERIES.}

LONDON :

THE RELIGIOUS TRACT SOCIETY;

Instituted 1799. 

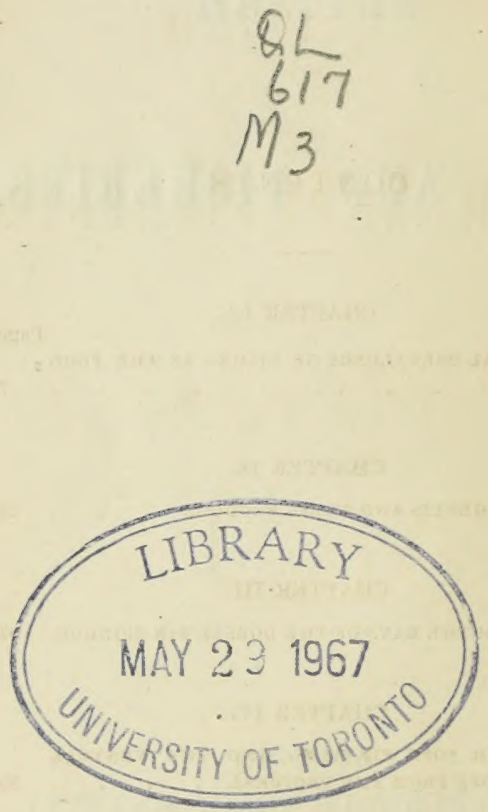


\section{CONTENTS.}

CHAYTER I.

Page

TIE GENERAL PREVALENCE OF FISHES AS THE FOOD

OF MAN . . . . . . . . . 7

CHAPTER II.

DITISII FISHLRIES AND TIEIR PRODUCE • • • - 2 t

\section{CIIAPTER III.}

TISHES WITH THE RAYS OF TIE DORSAL TIN SHINOUS 52

CHAPTER IV.

FISHES WITH SOFT FIN-RAYS, AND THE VENTRAL FINS REMOTE FROM THE PECTORAL • • - . 89

\section{CHAPTER V.}

FISHES WITH SOFT FRN-RAYS, AND THE VEXTRAL FINS DITECTLY BENEATH THE RECTORAL . • • 142 
CONTENTS.

CHAPTER Vi.

Pase

FISHES WTTHOUT VENTRAL FINS . . . . . 161

CHAPTFR VII.

GaRTILACINOUS FISIES . • • • . . 174 


\section{BRITISH}

\section{FISH AND FISHERIES.}

\section{CHAPTER I.}

THE GENERAL PREVALENCE OF FISHES AS THE FOOD OF MAN.

THE use of fish as an article of food is of remote antiquity. The Israelites, in their journey through the wilclerness, when pressed by scarcity of provisions, exclaimed, "We remember the fish which we did eat in Egypt freely, the cucumbers and the melons, and the lceks, and the onions, and the garlic;" and it is recorded, that among the plagues brought upon the Egyptians by Moses and Aaron, at the command of God, one was the turning of the water of the river Nile into blood, and the consequent destruction of the fish, Exod, vii. 19-21.

The effects of this destruction were severely 
felt, for fish formed an important part of the diet of the ancient inhabitants of Egypt. Among their paintings, not only fish-ponds in gardens are depicted, with the fish swimming about, but also representations of fishermen, some employed in using nets, * others, lines and hooks. Spears, as pictorial representations show, were also employed, and to these weapons we find an allusion in the book of Job, xli. 7 . The mosaic pavement of Præneste exhibits also a mode of taking fish in weirs, decoys, or toils, made of hurdles of reeds, winding in various directions, so as to entrap the fish, which are taken out by means of baskets or nets; see also Isaiah xix. 8-10.

Fish, according to Herorlotus, were eaten by the Egyptians lilie ducks and quails, both salted or pickled, and also dried in the sun, without any other preparation. From some motive or other, however, the priests were prohibited from the use of fish as food, and in the catacombs of Abousir, according to $\Lambda$ bdallatif, (an Arabian writer of the twelfth century, ) among the remains of other animals those of small fish were found. $\uparrow$

* See the use made by the inhabitants of the low marslies of Erypt of nets, namely, to take fish by day, to serre as mosquito curtains at night.-Herodotus; Euterpe.

† See De Sacey's Translation, n. 201. 
With regard to the fish kept by the ancient Egyptians in small ornamental ponds, as their paintings show to have been a general custom, it is probable they were consecrated, or held sacred; such a practice, at least, appears to have prevailed in the east from an early period, and is, perhaps, not yet exploded. "Sir John Chardin twice mentions fishes reputed to be sacred at this day in the east. In his third volume, he tells us, 'that at a town called Comicha, he found, in the courtyard of a mosque, two reservoirs, or basins of water, twenty paces from each other, full of fishes, some of which had rings of brass, some of silver, others of gold.' 'J. apprehended,' he says, 'that these fish had the rings in their nostrils, by way of ornament; but I was informed that it was in token of their being consecrated. None dared to take them; such a sacrilege was supposed to draw after it the vengeance of the saint to whom they were consecrated; and his votaries, not contented to leave them to his resentment, took upon themselves to punish the transgressors. An Armenian Christian, who had ventured to take some of these sacred fish, was killed upon the spot by one of them.' This is a relic of ancient superstition. Dr. Richard Chandler, in his Travels in Asia Minor, gives a 
note from AElian, who speaks of tame fishes, that wore gold necklaces and ear-rings, in a clear fountain, belonging to the military Jupiter."

That there were sacred fishes among the ancient Egyptians is proved, not only by their mummies found in catacombs of $A$ bousir, but by their representations on the sculptured monuments, with those of other animals to which idolatrous veneration was paid; and hence it might be, that though fishes were allowed as food to the common people, the priests abstained from them, lest their purity should be endangered. Other sacred animals indeed they eat, (the head excepted,) but the inconsistencies of their practice ought not to surprise us. The following note in the Pictorial Bible is not without interest, but it leaves the subject open to conjecture: "Diodorus says, that, from the time of the king Mœris, a great body of men found continual occupation in salting the fish caught in the lake dug by that prince. Diodorus also describes the Nile as aboumding in fish, not only sufficient to supply them with fresh fish, but to enable them to salt large quantities for exportation. He adds, with truth, that there was not in the world a river more serviceable to mankind than the Nile. The Egyptians are the first people whom history 
mentions as curing any kind of meat with salt for provisions. They used fossil salt, which they got from the African deserts; sea-sait, and everything belonging to the sea, being abhorred by them. The priests abstained eren from the fish of the Nile; but whether because they considered the natives of the river too sacred to be eaten by them, or too impure from their possible communication with the sea, authors are not agreed. Clement of Alexandria gives the former reason, and Plutarch the latter."

During their sojourn in Egypt, the Israelites adopted, more or less completely, the customs and even the superstitions rites of their masters, and hence, after their deliverance, arose the necessity of enjoining upon them a new code of laws, in order to draw a line of distinction between them and idolatrous nations. On this principle, the Levitical dispensation descends to the regulation of minutia of high importance, under the then existing circumstances.

Among these stringent laws are sereral respecting animals to be used or rejected as food; and we find that, though fishes generally were not forbirlden, (and perhaps under the term fishes other aquatic creatures are included,) those destitute of fins and scales were not to be eaten. "And all that, have not fins and scales 
in the seas, and in the rivers, of all that more in the waters, and of any living thing which is in the waters, they shall be an abomination unto you," Lev. xi. 10. From this we infer that shell-fish, as we term them, and other aquatic mollusks, as well as smooth, slippery, scaleless fishes, were prohibited; and perhaps the injunction more peculiarly applies to the former than to real fishes, as we now restrict the term. Be this as it may, fishes with scales were decidedly allowed, and evidently constituted a considerable portion of the food of the Israelites.

The lakes and rivers of Syria supplied them; and sea-fish from the Mediterranean were brought to Jerusalem, and other cities and towns of Palestine, by the Phœnician fishermen. who traded even on the Sabbath, to its profanation. "There dwelt men of Tyre also therein, (in Judah,) which brought fish, and all manner of ware, and sold on the sabbath unto the children of Judah, and in Jerusalem," Neh. xiii. 16. What was the fate of Tyre, the great and mighty city, "the daughter of Sidon," which eclipsed its parent in splendour? "It shall be a place for the spreading of nets in the midst of the sea," Ezek. xxvi. 5. Tyre was insular, or rather peninsular, being united to the mainland by the causeway of Alexander; 
crumbling ruins alone attest its grandemr ; a few huts, chiefly inhabited by fishermen, constitute the modern village of Tsour, (a rock,) and it is literally a place where fishormen spread their nets to dry. Volney, whose infidelity was avowed, says, "The whole village contains only fifty or sisty poor families, who live but indifferently on the produce of their little grounds, and a trifling fishery."

In Genesis xlviii. 16, Jacob, in giving his blessing to Ephraim and Manasseh, says, "Let them grow into a multitude as do fishes ;" * a sentence rendered in our common translation, "Let them grow into a multitude in the midst of the earth." The appropriateness of the comparison in the Hebrew is very striking, for the fecundity of fishes is astonishing. The most unceasing destruction by man, by birds, and by their warfare upon each other, appears not to dininish their multitudes; yet, perhaps, it is seldom the case that any individual of their countless hordes dies a natural death of old age-it destroys, and is destroyed. To counterbalance the loss there is a commensurate reproduction, and this and the havoc keep pace with each other. The following table from Harmer's paper on this subject, in * Or, "Let them, as fishes do, incrense." 
the Phil. Trans., 1767, may serve to convey some idea of the natural increase of fishes, and the necessity of a counterbalancing haroc; showing how wisely the $A$ lmighty has adapted the laws of existence to the great end to be answered :-

\begin{tabular}{|c|c|c|c|c|c|}
\hline Fish. & $\begin{array}{l}\text { Wei } \\
\text { of } \mathbf{F} \\
\text { exam }\end{array}$ & $\begin{array}{l}\text { ight } \\
\text { ish } \\
\text { intel. }\end{array}$ & $\begin{array}{l}\text { Weight } \\
\text { of live. }\end{array}$ & $\begin{array}{l}\text { Number } \\
\text { of } \mathbf{E g}=s .\end{array}$ & $\begin{array}{c}\text { Date of } \\
\text { Eximination. }\end{array}$ \\
\hline Carp & $\begin{array}{c}\text { OZS. } \\
25\end{array}$ & $\frac{\operatorname{grs} .}{5}$ & $\begin{array}{c}\text { Grains. } \\
2,571\end{array}$ & 203,109 & April \&. \\
\hline Coulis h & & - & 12,510 & $3,1-13.760$ & Decimber 23 . \\
\hline Flomincler & $2 t$ & 4 & $2,2(1)$ & $1,357,460$ & March 14. \\
\hline Herring & 5 & 10 & isu & 36,000 & Oetulier 25. \\
\hline Mackerel & 18 & 0 & $1,2 \div 3 \frac{1}{2}$ & $5: 6,6: 1$ & June 15. \\
\hline Perch & 8 & 9 & $765 \frac{1}{2}$ & 28,323 & April 5. \\
\hline Pike & 56 & 4 & $5,100 \frac{1}{2}$ & 49,304 & April 25. \\
\hline Roach & 10 & $6 \frac{1}{2}$ & $361^{2}$ & 81,556 & May 2. \\
\hline Smelt & 2 & 0 & $149 \frac{1}{2}$ & $35,27 s$ & March 21. \\
\hline Sole & 14 & 8 & $5+23$ & 100,362 & June 13. \\
\hline Tench & 14 & 0 & & 383,252 & May 28. \\
\hline
\end{tabular}

Mr. Yarrell obserres, that "Bloch found six hundred thousand ova (eggs) in the roe of a female carp of nine pounds' weight; and Schneider, seren hundred thousand in a fish of ten pounds' weight."

From the incidental comparison in the passage of Genesis, in question, we learn an interesting fact-that, from remote antiquity, the habits of animals have attracted observation; and that, as respects fishes, their extraordinary numerical increase was known eren to the patriarchs of old; or rather, so generally as 
to serve by way of a simile. Fishes were among the subjects of natural history on which Solomon is recorded to have written; but his writings on these things have not been preserved, probably because, not being of a character exclusively sacred, they were excluded from the archives of the priesthood.

At a far later period of the Jewish listory than that included in the Old Testament, the use of fish as food was very prevalent; * and we find that, on several occasions, our Saviour condescended to exercise his miraculous powers upon these creatures, thereby demonstrating that the laws of matter were subject to his control. We may first allude to the two miracles of the loaves and fishes. In both instances, it was adjacent to the Lake of Tiberias, or Gennesaret, also called the Sea of Galilee, (the Bahr-el-Tabarieh of modern days, ) that our Saviour fed the hungering multitude. This lake is from twelve to fifteen miles long, and from six to nine wide, and is surrounded by mountaius and beautiful scenery. The water is cool and clear, and at the present day abounds with fish, while its borders are the resort of innumerable water fowl. The course of the

* "If a son shall ask bread of any of you that is a father, will he give hin a stone? or if lie ask a fish, will he for a fish give hum a serpent?" Luke xi. 11. 
Jordan may be distinetly traced by a smooth current right through the centre of the lake.

The first of the two miracles referred to occurred in a desert situation, where five thousand men, besides women and children, were collected to hear the words of life from the lips of Him who "spale as oue having authority; " and five loaves and two fishes not only supplied them with sufficient food, but even a superfluity: "They did all eat, and were filled: and they took up of the fragments that remained twelve baskets full." See Matt. xiv. 17-20.

On the second occasion, four thousand men, beside women and children, on whom the Saviour had compassion, were fed with seven loaves and a few small fishes, and of the broken meat that was left were seren baskets full. See Matt. xv. 32-39.

It was at Capernaum, on the borders of the same lake, that our Saviour, in order to procure tribute money, (a didrachma, or about fifteen pence per head,) again displayed his miraculous power, by commissioning a fisb to contribute to his necessities; "for thongh he was rich, yet for our sakes he became poor, that we, through his porerty", might be rich," 2 Cor, viii. 9. It was then that $\mathrm{He}$ di-- 
rected Peter, saying, "Go thou to the sea, and cast an hool;, and take up the fish that first cometh up; and when thou has opened his mouth, thou shalt find a piece of money: that take, and give unto them for me and thee," Matt. xvii. 27. The money was a tetradrachmon, or stater, a double didrachma, (four drachmx,) equivalent to the Hebrew shelel. Thus, then, did our adorable Recleemer set us the example of rendering to Casar the things which are C'rsar's ; even while he proved, by a miracle, his Divine nature, as "the Christ, the Son of God," and the Saviour of all who come to Him by the leading of the Ioly Spirit.

Nor are these all the miracles which the Redeemer wrought, bearing upon the scaly tribes of the water. It was upon the same lake that he directed the casting of the net, which broke with the weight of the fish it inclosed, such was the multitude captured, to the astonishment of Simon Peter and his partners, James and John, who were with him. See Luke v. 1-11. The words of our Lorri on the occasion, "from henceforth thou shalt catch men," show us at once the meaning which was intended to be conreyed. These humble fishers were hereafter to throw the net of the gospel, which must ever be the work of their 
faithful successors; and thus are they enjoined to draw men from the depths of sin and destruction to the glorious light of that revelation, sent in mercy to beam upon the path which leadeth to the kingdom of heaven, where $\mathrm{He}$ who bore our sins in his own body on the cross ever liveth to intercede in behalf of all who come unto God through him.

But again, upon the same lake, a somewhat similar occurrence took place. It was after his glorious resurrection that our Redeemer visited the shores of that beautiful sea of Tiberias, which had witnessed so many of his miracles, and where he had so often preached the words of eternal life. On that shore several of his disciples were now collected. "There were together Simon Peter, and Thomas called Didymus, and Nathanael of Cana in Galilee, and the sous of Zebedee, and two other of his disciples. Simon Peter saith unto them, I go a fishing. They say unto him, WVe also go with thee. They went forth and entered into a ship immediately; and that night they caught nothing. But when the morning was now come, Jesus stood on the shore: but the disciples knew not that it was Jesus. Then Jesus saith unto them, Children, have ye any meat? They answered him, No. And he said unto 
them, Cast the net on the right side of the ship, and ye shall find. They cast therefore, and now they were not able to draw it for the multitude of fishes. Therefore that disciple whom Jesus loved saith unto Peter, It is the Lord.

"Now when Simon Peter heard that it was the Lord, he girt his fisher's coat unto him, (for he was naked,) and did cast himself into the sea. And the other disciples came in a little ship, (for they were not far from land, but as it were two hundred cubits, dragging the net with fishes. As soon then as they were come to land, they saw a fire of coals there, and fish laid thereon, and bread. Jesus saith unto them, Bring of the fish which ye have now caught. Simon Peter went up, and drew the net to land full of great fishes, an hundred and fifty and three : and for all there were so many, yet was not the net broken." John xxi. 2-11.

Such were the miracles connected with fish, which Christ wrought, at the honoured sea of Tiberias, the lake of Galilee. Several of his disciples, Simon and Andrew, James and John, the sons of Zebedee, were fishermen. This cireumstance is thus commented upon by Izaak Walton: "They that occupy themselves in deep waters, see the wonderful works of God," 
-indeed, such wonders and pleasures, too, as the land aftords not. And that they be fit for the contemplation of the most jrudent, and pious, and peaceable men, scems to be testified by the practice of so many devout and contemplative men, as the patriarchs and prophets of old, and of the apostles of our Saviour in our latter times; of which twelve, we are sure ha chose four that were simple fishormen, whom he inspired and sent to publish his blessed will to the Gentiles, and inspired them also with a power to speak all languages, and by their powerful eloquence to beget faith in the unbelieving Jews; and themselves to suffer for that Saviour whom their forefathers and they had crucified, and in their sufferings to preach freedom from the incumbrances of the law, and a new way to everlasting life. This was the employment of those happy fishermen, concerning which choice some have made these observations. First, That he never reproved these for their employment or calling as he did scribes and the money-changers. And, secondly, He found that the hearts of such men, by nature, were fitted for quietness and contemplationmen of mild, and sweet, and peaceable spirits : these men our blessed Siviour, who is observed to love to plant grace in good natures, though, 
indeed, notling be too hard for him, yet these men he chose to call from their irreprovable employment, and gave them grace to be his disciples, and do wonciers ; - I say four of twelve."

"And it is observable, that it was our Sariour's will that these four fishermen should have a priority of nomination in the catalogue of his twelve apostles. Matt. x. 2 ; Acts i. 13 ; -as, namely, first St. Peter, St. Andrew, St. James, and St. John, and then the rest in their order. And it is yet more observable, that when our blessed Saviour went up into the mount, when he left the rest of his disciples, and chose only three to bear him company at lis transfiguration, that those three were all fishermen. And it is believed that all the other apostles, after they betook themselves to follow Christ, betook themselves to be fishermen too; for it is certain that the greater number of them were found together fishing by Jesus after his resurrection, as it is recorded in the 21 st chapter of St. John's Gospel."

Turning from the Egyptians and Israelites to the Greeks and Romans, we find that fish was in great request among those people; and among the latter in particular several sorts were in high estimation. They luad fish-ponds, or vivaria, supplied, as the need might be, with fresh or sca-water, and in these the fishes were 
kept and fed with great care, and at considerable cost. Amongst these was the muræna, a species which often attains to five feet in length, and is armed with horrible jaws; it is said that refractory slaves were often thrown alive to these fishes to be devoured. They were kept in vast numbers; for Cæsar, on the celebration of one of his triumphs, is reported to have distributed six thousand specimens among his friends.

Another celebrated fish was the scarus, (Scarus creticus aldrovand.) This is a native of the Greck sea, and was sent to Rome at great cost, while expensive attempts were made to naturalize it along the shores of Italy. " $N^{r} u n c$ scaro datur principatus"-Now the pre-cminence is given to the scarus, says Pliny ; but whether it deserved so high a reputation is questionable. At the present day, Cuvier informs us, it is eaten in Greece with a sauce of its own intestines. The turbot (Rhombus) was valued both by the Greeks and Romans, as it is still among ourselves; though we must say, in our humble opinion, more highly than it really merits. The flesh is white, and remarliably firm and close. It was a monstrous fish of this species, which from its size astonished the emperor Domitian, who ordered a consultation of the senate, in order to derise the best way of bringing it to the table. The 
anchovy (Encrasicholus engraulis, so common in the Mediterranean, was also known to the - Greeks and Romans, who prepared a sauce from it, much perhaps as we do now; it was called garm. Another sauce or pickle, made from the tunny, was called muria, but it was less esteemed than gamm. There was also another fish sauce, called aler, or halex; and salt fish was also used in abundance. It was sold in the Forum Piscatorium, by the salsamentarii, or fishmongers. Fishing was a favourite amusement among the Romans; they used both lines and nets. Suetonius states, that Nero was accustomed to fish with a net of gold and purple; and we learn from Plutarch, that angling was one of the principal recreations of the luxurious Anthony and Cleopatra.

We need not extend our review to other nations of antiquity, among whom, as in the present day, fishes were of more or less importance as an article of food; and upon which, if indeed we are to credit historians, some people exclusively subsisted; such were the Ichthyophagi, who, according to various authorities, not only lived entirely on these creatures, but even constructed their habitations of the bones. 


\section{CHAPTER II.}

BRITISH FISHERIES AND THEIR PIODUCE.

To come to modern days, there are few nations, it may be observed, which do not make use of fishes as food; our remark applies equally to savage as to civilized people, from the Greenlanders and Samoiedes, to the natives of the most polished states of Europe. The sca, the great lakes, and the rivers of the globe, constitute so many boundless magazines, which through ages past have afforded, and for ages to come will afford the supply appointed by Almighty wisdom. So important to a nation, indeed, are its fisheries, that they are made the subjects of legislation, their boundaries in the sea are determined by international compacts, the seasons are prescribed, and the size even of the meshes of the nets employed are regulated by law.

With respect to Great Britain, her fisheries extend not only around the coast, but are car- 
ried on in more distant places, and among them we may particularize those of Newfoundland and the coast of Labrador. "The great bank of Newfoundland is the principal station of the distant cod-fishery; the fish found on it being not only of excellent quality, but in the greatest abundance. The bank began to be resorted to by fishers early in the sixteenth century. In 1578 , France had on the bank of Newfoundland 150 vessels; Spain, 120 or 130 ; Portugal, 50 ; and England, from 30 to 50 . During the first half of the last century, the fishery was principally carried on by the English (including the Anglo-Americans) and the French; but the capture of Cape Breton, and of their other possessions in America, gave a severe blow to the fishery of the latter.

"The American war divided the British fishery; that portion of it which had been previously carried on from New England being thereafter merged in that of the United States. Still, however, we contrived to preserve the larger share. At an average of the three years, ending with 1789 , we are said to have had 402 ships, 1,911 boats, and 16,856 men, engaged in the American fisheries. During the last war, the French being excluded from the fisheries, those of England attained to an 
extraordinary degree of prosperity, the total value of the produce of the Newfoundland fishery in 1814 having exceeded $£ 2,800,000$. But since the peace, the British fishery on the Newfoundland banks has rapidly declined, and can hardly, indeed, be said at this moment to exist. It is now almost entirely carried on by the French and Americans; the facilities enjoyed by the latter for its prosecution being greater than those of any other people, and the former being tempted to engage in it by the extraordinary encouragement afforded by government.

"At present, the British fishery carried on by the inhabitants of Nerfoumdland is confined entirely to the shore, or boat-fishery. The average anmual produce of the fisheries of all sorts, including seal, salmon, etc., exported from Newfoundland during the three jears ending with 1832 , is stated by $\mathrm{Mr}$. $\mathrm{M}^{\circ}$ Gregor at

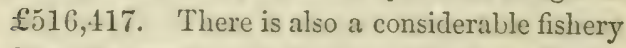
from the ports and harbours of Nova Scotia, Cape Breton, New Brunswick, etc. But next to that of Newfoundland the principal British fishery is carried on along the coast of Labralor, its prouluce being estimated at from $£ 300,000$ to $£ 350,000$ a year." *

* MrCulloch. 
The exportation of fish from Newfoundland in each of the years, 1832,1833 , and 1834 , was as follows :-

\begin{tabular}{|c|c|c|c|c|c|}
\hline & & & 1832. & 1833. & 1834. \\
\hline Cod, dry. . crit. & : & & $\begin{array}{l}619,177 \\
658\end{array}$ & $\begin{array}{r}8 \$ 3,536 \\
3,633\end{array}$ & 763,187 \\
\hline Herrings. . boxes & : & & 86 & & \\
\hline Do. .. barrels & & & 1,728 & 2,039 & $1,623 \frac{1}{3}$ \\
\hline - do & & & & 326 & \\
\hline Salmon .. do. & & & 2,690 & 3,256 & 3,363 \\
\hline \multicolumn{2}{|c|}{ Yalue of fish exported. } & & 319,265 & 455,672 & $443, \overline{5} \div 7$ \\
\hline
\end{tabular}

In 1836, the number of British ressels engaged in the Nerfoundland and Labrador fisheries amounted to 94, with 721 men. The boats employed were 11,427; fishermen and boys, 49,720; coopers, 1,916 ; fish-curers, 1,916 ; persons employed in cleansing, drying, and packing the fish, 26,038; labourers, 7,235 ; barrels of herrings, 497,615 ; quantity of cod cured and dried, 38,040 ewts.; pickled, 6,276 barrels.

To return to our own shores. Our home fisheries, as it respects the property embarked in them, the number of men employed, and the value of their produce, are, in a commercial and political sense, of high importance. The claim to certain fishing-grounds has been settled by treaties between the British government and those of the adjoining kingdoms of Europe; and the invasion of these stations, or the forcible 
exclusion of parties pretending to the rights of fishery within the assigned limits, has led to reprisals, to hostile proceedings, and even to serious disputes between the governments interested in the settlement of the question. Hence, at various times has the attention of the legislature been directed to the establishment of regulations, and cncouragements have been given to those who embarked property in the speculation.

In the ninth century, the herring fishery was extensively pursued in Scotland, but when the convention of royal burghs prohibited the exportation of fish before the resident population was supplied at a given price, the fishery declined, and many of the fishermen settled in Holland, which drew the attention of the Dutch to the Scotch fisheries. The Dutch hare at present fisheries on the Doggerbank, and at Feroè. During the year 1845, 187 sloops lefo Ostend for the fishery at the Doggerbank, and 12 for Feroë. They brought back 9,43:2 tons from the former ground, and 1,215 from the latter; total, 10,647 tons, being less by 1,105 tons than were procured in the year 1844 . Several enactments were framed under James III, w., V., and vi., of Scotland, (before the latter ascended the English throne, for the restoration 
of the Scottish fisheries, but with only partial success.

In 1633, Charles I. ordained an association of the three kingdoms, governed by a standing committee, and for the better encouragement of the adventure enjoined the strict observation of Lent-an impolitic step, which the breaking out of the civil war interrupted. During the Protectorate little was done, excepting a remission of salt duties, and excise duties on naval necessaries, in favour of private parties engaged in the fisheries; but Charles Ir. appointed, in 1677 , a council of royal fishery, in order to the establishment of laws and regulations; and for the encouragement of those engaged in this branch of commerce "a lottery was granted for three years, a collection was made in churches, and an exemption granted for seven years from customs, both inwards and outwards, on the sale of fish exported to the Baltic, Denmark, Norway, France, and some other countries. Besides this, all victuallers and coffeehouse keepers were compelled each to take a certain number of barrels of herrings yearly, at 30s. per barrel, until a foreign market could be established to the satisfaction of the council. Beyond these encouragements, a duty of $2 s .6 d$. was imposed upon foreign herrings imported, 
and a promise was made of all such other advantages as experience should discover to be necessary." No advantage permanently resulted from these stringent regulations, and after sixteen years of disappointment, a charter was granted to a new fishing company, haring

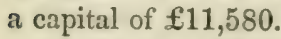

In the year 1690, this company was again renewed, and on its failure was dissolved by act of parliament in the early part of the reign of William ur. Other efforts were subsequently made, but were all unsuccessful. In the year 1749 , "The Socicty of the Free British Fishery" was formed under act of parliament, with a capital of $£ 500,000$. A bounty of 36 s. per ton on all decked vessels of from twenty to eighty tous employed in fishing was granted for fourteen years; in 1657, the bounty was increased to 56 s. per ton, and in 1759 to 80 s. per ton, besides a grant of $2 s$. $8 d$. per barrel upon all fish exported; interest, moreover, at the rate of 3 per cent, being secured to the subscribers, payable out of the customs' revenue. Eight vessels only were entered on the custom-liouse books for the fisheries, notwithstanding the encouragement, and the scheme proved futile.

In the same year, 1759 , the whole of the buss (small ressels) fishery of Scotland hrought in 
only four barrels of sea-sticks, or herrings cured at sea, each of which, in bounties alone, cost the government $£ 113.15 s$, and each barrel of mercantile herrings cost £159. $7 \mathrm{~s}$. Gol. Adam Smith, who records the fact, gives the explanation thus, namely, that the bounty being given to the vessels and not to the fish, ships were equipped to catch the bounty and not the herrings.

In the reign of George mi., (1786,) a different regulation was appointed by act of parliament ; a bounty of 4 s. per barrel was given on fish, the tonnage bounty was reduced to $20 s$, limiting the whole payment to 30 s. per ton, excepting when more than three barrels per ton were taken, in which case 1 s. per barrel was given on the excess. We learn that, on " an average of ten years, 54,394 barrels were annitally taken, at a cost to the government, (or xather the nation,) of about $7 \mathrm{~s} .6 \mathrm{~d}$. per barrel."

In 1808 , the bounty was again raised to $60 s$. per ton, on decked ressels of not less than sixty tons' burden, employed in the deep sea herring fishery, with an additional bounty of 20 s. per ton to the first thirty vessels which should be entered the first year. Besides this, a sum of

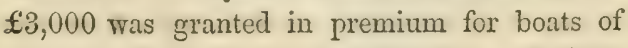
not less than fifteen tons' burden. Vexious 
regulations respecting the curing and barrelling of the fish, chiefly borrowed from the Dutch, were laid down, and a board consisting of seren commissioners was appointed for seeing that the provisions of the act were strictly carried into operation. In 1815, this act was confirmed, but the bounty extended to vessels of forty-five tons: burden; and, in 1817, while there was a heavy duty on salt, the use of this article for the curing of fish was permitted duty free.

Notwithstanding all this, the fishery could not be said to be in a truly stable or flourishing condition-the system of bounties was radically wrong. The business was forced and fictitious, and Mr. MI'Culloch well observes: "Its extension under the circumstances in question, instead of affording any proof of its being in a really flourishing condition, was distinctly the reverse. Individuals without capital, but who obtained loans sufficient to enable them to acquire boats, barrels, salt, etc., on the credit of the bounty, entered in vast numbers into the trade. The market was most commonly glutted with fish, and yet the temptation held out by the bounty caused it to be still further overloaded. Great injury was consequently done to those fishcurers who possessed capital, and eren the fishermen were injured by the system. 
"Most of the boats employed in the fishery never touch the water but during six weeks, from the middle or end of July to the middle of September. They are owned and sailed, not by regular fishermen following that vocation only, but by tradesmen, small farmers, farm-servants, and other landsmen, who may hare sufficient skill to manage a boat at that season, but who do not follow the sea, except for the six weeks of the herring fishery, when they go upon a kind of gambling speculation of earning a twelvemonths' income by six weeks' work." * It has been often said, in vindication of the bounty system, that by extending the fishery it is an important nursery for seamen, but the preceding statement shows that such has not been the effect. On the contrary, it has tended to depress the condition of the genuine fisherman by bringing a host of interlopers into the field of speculation; and it has been also prejudicial to the little farmers and tradesmen, by withdrawing their attention from their peculiar business that they may embark in what has been hitherto little less than a sort of lottery adventure. 'The system was in fact demoralizing; it was a bounty on idleness and perjury; it acted as a clog upon industry, and

* Quarterly Journal, Noo. xi. p. 653. 
a check to reliance upon personal exertions independent of extranenus aid; nor could it be otherwise than impolitic, since it imposed a tax upon the nation, in order that other countries might be supplied with articles of consumption at prices below their actual cost.

In due time, however, this impolicy began to be acknowledged. In 1821, the tonnage duty of $60 \mathrm{~s}$. was repealed, but a bounty of $4 \mathrm{~s}$. per barrel was continued up to the year 1826 . After this, it was reduced by 1 s. each jear, thereby ceasing in the year 1830. Nor was the reduction and ultimate abolition of this bounty productive of any injury to the herring fishery; on the contrary, according to Mr. Ternan, the houses of the fishermen of Skerries (a village on the cuast of Lancashire) are neater and contain more comforts than formerly, and the men are better clothed, better fed, and more sober and industrious. The same observations apply to Scotland, where the fishermen hare better and larger boats, and fishing utensils of higher value, than those they possessed while the system of bounty was in operation.

"The greater part by far of the British herring fishery has been long carried on from different places, principally on the east coast of Scotland, of which Wick, in Caithuess, is the 
principal.* Of the 397,737 barrels of herrings reported by the Fishery Commissioners to have been cured in the year ending 5 th of April, 1837, 33,089 were cured at Wick, 32,584 at Fraserburg, 29,872 in Shetland, 22,790 at Bamff, 18,706 at Helmsdale, 19,091 at Rothsay, 15,831 at Lybster, etc. None were cured in the Isle of Man, formerly one of the principal seats of the fishery. The Yarmouth fishery, though much fallen off, is still prosecuted to a considerable extent. About one hundred sail of fishing vessels, averaging from forty to fifty tons each, belong to that port, exclusive of about fifty or sixty vessels that arrive annually from Yorkshire during the he ring season. The capital employed is estimated at about $£ 250,000$. Lowestoft, nine miles from Yarmouth, employs about serenty boats of forty tons each. The greater number of the herrings taken at Yarmouth are smoked, and known in London by the name of Yarmouth bloaters." $\dagger$ Hastings and Folkestone hare good herring grounds, and supply the London markets with fresh

* Pulteney Town, the suburb of Wick, on the south side of the bay, has within the last few years rapidly increased. During the fishing season, from 1,500 to 2,000 boats, laving each on an average a crew of five men, rendezwous here. Of these, 500 boats belons to the town, the others are from Northumberiand, and even the Hebrides.

$+\mathrm{NI}$ 'Culloch. 
fish. Herrings are also taken in Cardigan and Swansea Bays. In Ireland, herring fisheries are carried on along the coast of Donegal, in the estuary of the Shannon, on the coast between Dingle Bay and Kenmare, in Bantry Bay, and on the Wicklow const, as well as at other stations.

With respect to codfish, coalfish, ling, hake, torsk, haddock, etc., the fishery is carried on in a great variety of places. We may especially notice the Orkney and Shetland Isles, and the Doggerbank. The coast of Aberdeenshire is noted for haddocks of the finest quality.* Within the last few years, some migratory movement has bronght great quantities of cod along the coasts of Lincolnshire, Norfolk, Suffolk, and Essex-a circumstance which has made considerable alteration in the fishery, and the price of these fish in the London market. The fishing smacks belonging to Barking, Gravesend, and other ports on the 'Thames, have become much increased in number to the reduction of those of Harwich, and more distant ports. 'The Harwich store-boats, with wells for the preservation of the fish alive, used formerly to come up the Thames as far as Gravesend, and send up a portion of their cargo

* They are cured at the village of Finnan, near Aberdeen. A Finnan haddock is much esteemed as a delicacy. 
every night by the tide to Billingsgate, till the well was emptied; these vessels are by no means so numerous as formerly. We may here observe, that the Doggerbank cod is distinguished by a sharp nose elongated before the eyes, and by the skin being of a dark brown colour; this variety prevails on our southern shores. The Scotch cod has the nose round and blunt, short and wide, and the skin is of a yellowish ash-green. This short-nosed northern variety is now less frequently to be seen in the Londun shops than it was some years since. 'The cod, and other white fish, are in the highest perfection from October to the end of December.

The pilchard fishery, a fishery of some importance, is carricd on off the coasts of Cornwall and Devon, which are visited by migratory shoals in August and September, and also in November or December. About a thousand boats are said to be engaged in this business, giving employment to about 3,500 men at sea, and 5,000 men and women on shore. The fish are pickled in barrels, and exported to the continent. The average exports amount to about 30,000 hogsheads per annum. As regards turbots and soles, the former are rather rare on the English coast; the far greater number 
sent to the London market are obtained on the Dutch coast; they are chiefly taken by Dutch fishermen, and sold to the English. Turbot are also abundant on the sand banks in the Manche, where the French fishermen lay lines for them, and sell their prizes to the English. Turbot and dorg are taken along the Devonshire coast, and the former along the shores also of Durham and Yorkshire. The principal trawling-ground for soles extends along the south coast of England, but this fish is common on most of the sand beds round our coast.

Mackerel visit different parts of our coast, and are captured in vast numbers. They swarm in March and the spring months, along the coast of Sussex and Hampshire; somewhat later, they appear on the coast of Devonshire, and they also risit the southern shores of Ireland. It is from the coast of Sussex principally that the great supplies arrive in the London markets; * vast shoals often occur on the Suffolk coist.

* The price of mackerel in the Billingsgate market is very fluctuating. "It is sail, that if cluring the macherel season a vessel come to the whart at fire o'clock in the morning, when the market opens, the tish may sell from 4Ss. to $50 \mathrm{~s}$. a hundred. Whereas, if the same ressel came at ten 0 cloch, the mackerel would not be worth more than 36 s. a hundred; and if she came in the afternoon, they would not fetch more than $24 s$. or 2s8," 
The western and eastern coasts of our island are visited by the smelt, of which shoals, leaving the sea in August, migrate up the estuaries and so enter the rivers, where they sojourn until the following spring; there they deposit their roe, during the months of March and April, soon after which they return to the salt water. Along the line of our southern coast a fish called the atherine, or sand smelt, sometimes confounded with the true smelt, is found. It is, however, inferior to the latter, which does not occur, or only occurs rery rarely along the southern coast.* The whitebait in myriads visits the Thames, appearing in April, and continuing to September. The sprat abounds on our shores; in winter, many tons are brought to the London markets, and large quantities are sold as manure in Kent, Essex, Norfolk, and Suffolk. About forty bushels of sprats will manure a single acre, at the price of sixpence or eightpence a bushel.

London is supplied with vast quantities of eels, by far the greater number of which are brought alive from Holland.

We have hitherto said nothing respecting

* The true smelt has the second dorsal fin adipose, without rays, while in the atherine the second dorsal fin is membraneous, and supported by numerous rays. 
the salmon fisheries of Great Britain, which are carried on only in estuaries and rivers, up which they make their way, gaining the upper and shallow pools, where they make furrows in the gravelly bed for the reception of the egrs or roe of the females. This migration up the rivers takes place earlier or later, in autumn or spring, according to the peculiarities of the river or the condition of the fish; and soon after breeding, the salmon again gradually descend to the sea; consequently, the spawning time varies, being earlier or later, according to circumstances. "Rivers issuing from large lakes afford early salmon, the waters having been purified by deposition in the Ialses, while, on the other hand, rivers swollen by melting snows in the spring months are later in the season of producing fish, and yield their supply when the lake rivers are beginning to fail." The more northern rivers, as a general rule, produce the earliest supply. In these, the fish commence their ascent in autumn, remain there during the winter, breed in November, and return to the sea at the commencement of spring, where they reside during summer. In the Scotch rivers, the close time extends from the 14th of September to the 1st of February, when, by act of parliament, every person catch- 
ing, or attempting to catch fish at that period,

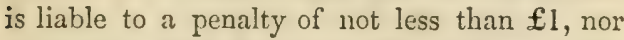
more than $£ 10$, for every offence, besides the loss of boats and implements employed. Much poaching, however, goes on, during the close or breeding season, to the great injury of the fisheries.* After breeding, they require some time to recover their condition, and consequently the number of fish obtained early in the spring, in a proper state for food, is small, compared with the quantity procured as the spring and summer advances. During the breeding season, the male is called a red fish, and the female a black fish, from the peculiarities of their colour. Haring spawned, and being unfit for food, the fish are called kelts; or the male is termed a kipper, and the female a baggit ; the young fry, called smolts, descend in March and April to the estuary, and so gradually to the sea, where their growth is amazingly rapid, for fry of seven or eight inches in length, marked in April or early in May, have returned by the end of June, or in July, from the sea to the river, weighing from two to three pounds and upwards, and already in a condition to breed. At this period, they are termed griles; and it is remarkable, that they push up the

* In Sweden, the salmon is said not to breed until June. 
river from the estuary and tideway earlier than the more adult fish.

Many English rivers produce salmon, at the Dee, the Esk, the Strern, the ITye, and rarely the Thames. There is good salmon tishing in some of the Trelsh rivers, but it is from the rivers of Scotland and Ireland that the markets are most abuudantly supplied, and these fisheries are mostly private property. London derives the principal part of its supply from Scotland; and Liverpool, Manchester, and the midland districts of England, from Ireland. Of the Scotch rivers, the Tweed is celebrated for its fishery. About thirty years ago, it produced a rental of from $£ 15,000$ to $£ 18,000$ per year. But from various causes it has lately declined to such a digree, that it cloes not yield abore $£ \notin, 000$ or $£ 5,000$ a year to its proprictors; the falling-off in this fishery, judging by the returns from Berwick, is from about 10,000 boxes, each averaging nine stone, to 3,000 boxes, shipped anumally from that port. Besides the Tweed, there are other rivers in Scotland with a valuable fishery, as the Tay, Forth, Dee, Don, Findhorn, etc., but all are mostly in the same condition as the Tweed. "There are everywhere complaiuts of the growing scarcity of fish; and the fact that the exports from the 
rentals of all the principal rivers have decreased during the last twenty years, shows that these complaints are but too well founded." Besides the system of poaching in close time, the weirs, salmon-traps, and other obstructions placed in the rivers, prove impediments to the fish in their ascent, and prevent many from persevering, while over-fishing has added its share: but, perhaps, the main cause may arise from the close time being too limited, which should commence as early as the middle of August, and continue to the close of February. It is now the practice to pack the Scotch salmon in coarsely pounded ice, by which means they arrive quite fresh in London, whereas formerly the greater part of the salmon caught in the Tweed, and other Scotch rivers, were pickled, or kitted, after being boiled, and sent to London under the name of Newcastle salmon.*

The Irish salmon fisheries of most note are in the Bann, near Coleraine; the Foyle; the

* Within memory, salted salmon formed a material article of economy in all the farm-houses of the Vale of the Tweed, as a considerable portion of their winter stores, inasmuch as that in-door servants often bargained that they should not be obliged to take more than two weekly meals of salmon. It could then be bought fresh caught in summer at two shilings the fish stone of nearly 19 pounds' weight. But from the introduction of ice enabling the whole to be sent fresh to London at all times, the price hardly falls below $12 s$. a stone, and is often $30 s$, and somethes $42 s, "-\Pi c r r$ 's Bertickshire. 
Billick, near Ballyshannon; the Boyne, abore Drogheda; and several others. Contrary to what has occurred in the Scotch rivers, the Irish salmon fisheries have increased of late years. Down to 1823 , the average produce of the Irish salmon fisheries did not exceed 40 tons, but from that period it has increased to an average of 140 or 150 tons ( 120 pounds to each cwt.) The sales of salmon, caught in the Bann, Foyle, and Moy, in 1835, amounted in Liverpool to $£ 9,000$; Manchester $£ 5,000$; Bristol, $£ 400$; Glasgow, £5550; Dublin, £300; Loudon (pickled), $£ 400$; and in the neighbourhood of the rivers, $£ 1,800$. Total, $£ 17,450$.

In June, 1846, the Fourth Annual Report of the Commissioners of Public Works on the sulject of the Fisheries of Ireland was presented to parliament. 'The result of it is, that, throughout 1845, there has been, on the whole, a steady, though slow progress towards improvement in the general fisheries of the country. The commissioners conclude their observations with these remarks and proposals (in speaking of the salmon fisheries and the close season) :-

"To the proposition of a uniform close season for the sea and tideways, we apprehend no well-founded objection can he advanced. 
"But a slight departure of uniformity in the upper or fresh water portions of the rivers, however apparently calculated to give rise to jealousies, will, we conceive, be found, upon investigation, judicious, and, in fact, to be the most expedient compromise (for such only it must be considered) that can be adopted.

"We are strongly impressed with the im portance, not only to the public, but also to the parties locally interested, or possessed of exclusive rights, of having the rivers fully stocked with a supply of early breeding fish, and of the consequent necessity of ceasing from all kinds of fishing for salmon at an early period of the autumn.

"Further, we believe, that to open any part of the month of January would, on the whole, be attended with more evil than good; and the few persons who have heretofore derived advantage therefrom, either under the provisions of the old laws, or by acting contrary to law, will participate largely in the benefits certain to arise from an improved system, efficiently carried out, and will be amply rewarded for any temporary loss they may sustain in being prevented from fishing in that month. We therefore propose-

"1. That in the upper or fresh water por- 
tions of rivers throughout Ireland, there shall be a uniform close season as regards every mode of fishing for salmon, from the 15th of September to the last day of February inclusive.

"2. That in the sea and tideways there shall be a uniform close season from the 1st of September to the 31st of January inclusive.

"3. That all net fishing for salmon and trout shall cease in the upper portion of rivers on the 31st of August; and that angling only for the fish shall be permitted until the 1 ath of September.

"Some doubt has been expressed whether angling might not be permitted to a later period than the 15th of September. But, after due consideration, we are opposed to any such extension, which would be an exceeding by so much of the open period fixed for the greater part of Scotland by the Act of 9 George IIr.

"If, in conjunction with a due observance of the limitation above proposed, suitable migration passes be left even in what are considered the best rivers in Ireland, and due protection be afforded during the close season, we confidently predict that, in the course of a rery few years, the parties most interested will find, in the improvement of the fisheries, that their advantage has best been consulted in the 
refusal to accede to the full extent of their demands.

"We wish further to repeat, and to impress upon the attention of all parties, that the rivers are the natural nurseries, not merely for the fisheries within their banks and at their mouths, but also for the public fisheries on the coasts, and that the times to be allowed for fishing therein must be regulated by a consideration of what is best, on the whole, for the public interest."

From the slight sketch we have thus far given of the extent and operations of the British fisheries, (for the chief statistial facts of which we are mainly indebted to Mr. M['Culloch, and an able article in the Penny Cyclopædia,) a tolerable idea may be formed of the national importance of this branch of commercial enterprise. It gives employment to thousands; it. is one of the sources of national prosperity. We hare said nothing of the oyster fishery, the lobster fishery, or the whale fishery, for these do not come within our present subject. Various are the estimates, from defective data, which different writers have given of the total value of the combined fisheries belonging to Great Britain. There are no means of arriving at accuracy; the sum, however, must be rery 
great. Sir John Barrow, in an article on Fisheries, in the new edition of the Encyclopxdia Britannica, estimates their total value, including foreign and domestic, at $£ 8,300,000$ a jear. This amount is regarded by $\mathrm{Mr}$. M'Culloch as an exaggeration, and he is of decided opinion that the entire value of the fisheries is within $£ 3,000,000$, or $£ 3,500,000$ per year; still an enormous and startling sum, sufficient to justify our previous observations.*

It is not easy to speculate on the influence which railroads, traversing the kingdom in all directions, will ultimately have upon the fisheries. It may be presumed that the means of rapid communication thus opened with the central counties will tend to the increase in those districts of the consumption of fish, where little in a fresh state had been previously made use of. In many instances, our central towns will, perhaps, be abundantly supplied directly from the coast; and at all events, orders for fish, given by the resident country gentry to London

* Looking at Cornwall alone, the fisheries situate on the south coast, principally at Looe, Polperro, Megavissey, Port Looe, Falmouth, and Mount's Bay, and on the north coast of St. Ives, produce, upon an average, 21,000 inogsheads of pilchards annually, and sometimes nearly double this number, and generally 2,000 tons of mackerel. The pilchards are cured largely for exportation, Italy being the principal market. There is also a creat home consumption of this fish in Cornwall and Devonshire. 
fishmongers, which a few years since it would have been useless to have sent, will be executed with such speed, that the same day on which the letter is posted, and certainly the next, will bring the fish in high condition to hand. The impossibility, therefore, of providing fish for an entertainment or dinner will be no longer a complaint. Thus, then, may we look for an increased consumption of this produce of the teeming waters throughout the whole of our island. To France, and the continental countries of Europe, where the interior towns are so remote from the coast, the above observations will even more strongly apply. In these countries, river and pond fish are in far more general requisition than in England, and the reason is obvious, there are no means of conveying sea fish fresh and fit for food into the interior of the country; and hence in many states, as in Germany, Austria, Prussia, etc., extensive ponds and sheets of water become profitable as fisheries, and great attention is paid to the maintenance of the stock. An acre of water will often let for as much, or more, than an acre of land, and yield the renter good profit.

With respect to the means employed in taking fish in the fisheries, we have hitherto said nothing. They vary according to the 
species, and the depth of the water; drift-nets, sweep-nets, seans, baited lines and hooks, weirs, or toils, are all in their turn adopted; but of these we shall speak more particularly when we come to the natural history of the particular species to which we shall restrict our observations.

In our brief survey of the fisheries, we confined our statistical obserrations entirely to such species as are caught in the sea, with the exception of eels, smelts, and salmon. Setting these latter aside, none are afforded by the waters of our lakes and rivers necessitating the employment of a stated body of professed fishermen. Tre may, perhaps, except the flounder, which ascends rivers, and is taken by the Thames fishermen as high up the stream as Teddington; it is, however, common along our consts, and is both a salt and fresh water fish. There is, moreover, a char fishery on the various lakes of Cumberland and Testmoreland; and some portions of Windermere and Coniston lakes rent pretty high; but we hare no means of ascertaining the quantity of fish captured. The usual mode of taking them is with sunken nets, or trammels with baits, and a few are caught.by the fly-fishers when whipping for trout. 
Trout, perch, carp, and tench, together with pike, are often to be seen at the London fishmongers', but they are sent expressly by the owners of the rivers or preserves, (in which they are taken by way of sport, or for the purpose of thinning the water, ) in the same way as pheasants are sent to the London dealers in poultry and game. Many, doubtless, are taken by poachers, for the sake of a precarious and dishonest livelihood. But with regard to the consumption of these fishes we have no statistical data; it is far larger in proportion in the rural districts of our island than in London, or in the chief towns. 


\section{CHAPTER III.}

FISHES WITH THE RAYS OF THE DORSAL FIN SPINOUS.

Frosr these details, let us next proceed to notice some of the fishes of the British Islands. It must be evident, that in a discursive sketch like the present, we shall be able only to make a selection of such as are most likely to come under the observation of the general reader, or have more than ordinary interest. Of these some are river fishes, others are exclusively confined to the sea, while others, again, inhabit both salt and fresh water. Without respect to these particulars, we shall follow a scientific arrangement, but, at the same time, forbear from entering into details, which are rather more proper for purely scientific works than popular treatises. A few brief preliminary observations, however, may be permitted.

It is necessary that the reader should know 
the names of the fins, which are not only important organs, but afford, by their structure, position, and number, definite characters for the establishment of orders, families, and genera. They are supported by bony or by cartilaginous rays; they are thus designated :-

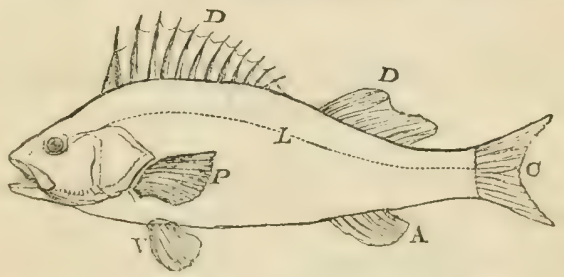

Dorsal fins, on the hack, D D. Pectoral fins, $r$. Ventral fins, V. Anal fin, A. Caudal fin, C. The formula for expressing the number of fins, the number of fin-rays and their condition, taking the perch by way of example, is thus written, D 15. $1+13$. P 14. v $1+5$. A $2+8$. C 17. The meaning is as follows: $\mathrm{D}$, dorsal fin, has fifteen rays, all spinous; the second dorsal fin has one ray spinous +13 that are soft. $P$, pectoral fin, with 14 rays soft. $v$, ventral fin with one ray spinous +5 soft. A, anal fin, with 2 rays spinous +8 soft. c, caudal fin, with 17 rays.

Along the sides of fishes is a row of scales, 
forming what is termed the lateral line. These scales are pierced through near the centre by a little tube that allows the exudation of the giutinous or mucous secretion, produced by glands beneath, and which thence spreads over the surface of the fish, defending it from the action of the water; this line is seen in the figure at $\mathrm{L}$.

The gills of fishes are in general fringes on gill-arches, as may be seen in the lerring or salmon, protected by gill-covers (operculun.)

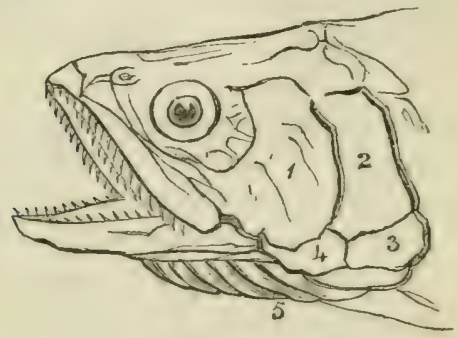

Each gill-cover, or operculum, is divided into five parts : 1 , The pre-operculum; 2, The operculum; 3 , The sub-operculum ; 4, The interoperculum; 5, The branchiostegous* rays. In some fishes, as the eel, the branchial aperture is very small, and placed far behind the * Gill-covering rays. 
cavity containing the gills themselves. In the shark tribe, the gills are fixed, there are no true gill-covers, the water escaping through fine branchial apertures on each side. In the flat skates, the mouth, nostrils, and branchiai orifices are on the under surface, and the eyes on the upper surface, near which are two temporal orifices, which, while the fish reposes supine on the mud, admit the entrance of the water into the respiratory or branchial cavity, and also its exit. In the lamprey, seven orifices on each side of the neck lead to so many cells, performing the office of gills, and through these orifices the water is received and expelled. The teeth in fishes vary exceedingly; in some species they are disposed upon the jaws, the palate, the tongue, and the throat; in others, the mouth is destitute of teeth, while the throat or phary'nx is provided with them. 'They differ also very greatly in form ; in some fishes they are constructed for crushing; in others, for cutting ; in others, for prehension ; but in every instance their character accords with that of the food upon which the species habitually subsist.

Fishes are divided into two great primary sections, namely, the osseous and the cartilaginous. In the osseous fishes, the bones of the 
skeleton are firm and hard, though less so than in quadrupeds or birds. In the cartilaginous fishes, such as the shark, the skates or rays, the lampreys, etc., the bones of the skeleton are never completely ossified; they permanently exist in a state of tough firm cartilage.

These two sections are resolved into sereral orders, each order comprising numerous families, composed of genera, in near relationship with each other. The first order of the osseous series is termed the acanthopterygious, (Acanthopterygii,) which, in plain English, means "fishes with the fin-rays of their dorsal fin spinous, or, at least, mostly spinous." Of this order the perch family (Percida) is very conspicuous.

The perch (Perca fuviatilis) is too well known to need any detailed description. It is distributed over the whole of Europe, living in rivers, lakes, and large ponds; it is remarkable for beauty, and the sharpness of the spines of the first dorsal fin, by which latter the hands of incautious or inexperienced fishers are often severely lacerated. These spines serve as very efficient defensive weapons, so that a good-sized perch need not fear eren the ferocious pike. The perch is gregarious in its habits, and frequents the still and quiet parts of rivers, 
rather than the rapid and turbulent. Worms, small fish, as minnows, and frogs, are its usual prey; it is bold and ravenous, and eagerly seizes the bait; and, says Walton, "as one has wittily observed, if there be twenty or forty in a hole, they may be at one standing all catched one after another, they being, as he says, like the wicked of the world, not afraid, though their fellows and companions perish in their sight." During the winter, however, excepting the day be warm, the perch can seldom be taken by the angle, nor does it bite freely till the mulberry tree buds, that is, until the chilly portion of the spring is over.

The perch will live long out of the water, and in a basket of wet moss may be carried to a very great distance, especially if a little water be occasionally poured over it. On the continent, where fresh water fishes are much in request, perch are often carried in this manner to market, and if not sold at the close of the day, taken back, replaced in the pond, and thus reserved for another occasion. The breeding season of this fish is about the beginning of May.

The perch seldom attains a very great size; a fish of the weight of half a pound or a pound is fine, and one of two or three pounds may be 
considered as extremely large, yet there are instances on record of perch being captured weighing six, eight, and even nine pounds; the ponds at Richmond-park, as we are informed by Mr. Yarrell, have yielded perch of four pounds.

Closely allied to the perch is the ruffe, or pope, (Acerina vulgaris,) common in the canals and slow shaded streams of England, especially such as have a gravelly bed. This fish seldom exceeds six inches in length; the scales are rough, and the dorsal fin is single. In habits and manners it resembles the perch, and its flesh is excellent. "No fish that swims is of a pleasanter taste; he is a greedy biter; and they will usually lie, abundauce of them together, in one reserved place, where the water is deep and runs quietly." The general colour of this fish is brown above, passing into a yellower tint on the sides, the under surface being silvery. The back dorsal fin and tail have darker spots or markings; the lateral line is very strongly marked. Fin-rays, D $14+12$. P 13. v $1+5$. A $2+5$. c 17 .

A sea fish, termed the basse, or sea-dace, (Labrav lupus,) which may indeed be called a sea-perch, is very common around the more southern shores of our island, and abounds also 
in the Mediterranean. It was known to the Greeks and Romans. The former termed it labrax, from its voracity; the latter, lupus, or wolf, for the same reason. This fish wanders in shoals, and often ascends rivers, even beyond the tideway; it will, indeed, live altogether in fresh water, and numbers, as Mr. Yarrell observes, have been retained with success in Mr. Arnold's fresh water lake in Guernsey, to the improvement of their excellence for the table. This species is mostly taken in nets, but often by hooks attached to deep sea-lines; they may be caught also during the flood-tide with a long rod and strong line, from a pierhead, or other projecting situation; they bite freely, and feed on the fry of fishes, on small crustacea, and marine insects. The basse usually measures from twelve to twenty inches in length, but is sometimes canght weighing from ten to fifteen pounds. The flesh is very good.

The general colour of the back is a dusky blue, passing into silvery white beneath ; the fins are pale brown; there are two dorsal fins, and, as in the perch, there are two external openings to each nostril. Fin-rays, D 9. $1+12$. P 16 . V $1+5$. A $3+11$. c 17 .

Among the fishes which, from antiquity, have been celebrated for their excellence, must be 
ranked the striped red mullet, or striped surmullet, (Mullus surmuletus, ) a species which was in high esteem at Rome, both on this account and also on that of its great beauty. The red mullet is common in the Mediterranean; it also visits the line of our southern coast, especially during May or June, when the shops of the London fishmongers display great numbers in high perfection. This richly coloured fish usually measures from twelve to fifteen inches in lengtlr, but larger specimens are occasionally taken, and in the Mediterranean it is not unusual to capture individuals of two pounds' weight.

In ancient times a mullet of large size was an object of great admiration, and sometimes even of contention. "A fish of three pounds' weight," says Mr. Yarrell, "produced a considerable sum to the fortunate fisherman ;" while " the cost of a fish of four pounds and a half," says Martial, "was ruinous. A mullet of six pounds is recorded to have produced a sum equal to $£ 48$; one still larger $\mathfrak{£} 64$; and even $£ 240$ were given for three, of very unusual size, procured on the same day, for a repast of more than usual magnificence." 'The Romans kept mullets in their vivaria, or preserres, but not with much success, as they do not increase in size during confinement. An allied species, 
of smaller size, and still greater beauty, the plain red mullet, (Mullus barbatus,) the Romans were accustomed to keep in vases, as we do gold fish, for the sake of the richness of their colouring. This species is very rare on our coast; indeed, only three or four instances of its capture are on record.

The flesh of the striped red mullet is white, firm, and of excellent Havour. In taking this fish, the trawl net is generally employed, as this species usually keeps low near the bed, associated in shoals. These often shift their ground, so that, although sometimes great numbers are taken, at other times, the fisherman is less successful. Occasionally, these fishes are captured in mackerel nets, near the surface. The striped red mullet has the lower jaw furnished with two long barbels, or cirri; the dorsal fin is double. The general colour is pink, passing into white on the under parts, with three or four yellow stripes along the sides. The slightest force is sufficient to remove the scales of this fish, and produce an extravasation of blood below the cuticle; and hence it is that, when at the fishmongers', it appears irregularly marbled with purple and bright red, the result of its struggles when caught. The striped red mullet breeds in spring, and the young attain 
the length of five inches in the course of the summer and autumn. Small crustacea and molluscous animals constitute its food. Finrays, D $7.1+8$. ₹ 17 . $11+5$. A $2+6$. c 13 .

We may now pass on to another family, termed the "hard-cheeked," from the singular characters presented by the head, which is armed with spines and cuirassed, or defended with osseous plates, giving a peculiar aspect. To this family belong the gurnards, of which six species, three common, the others rare, are found on our coast. In the gurnards, the head is square, and corered with bony plates; the gill-covers and shoulder-plate end in a spine directed backwards; the body is elongated; there are two dorsal fins, the first spinous; and there are three detached rays at the base of each ample pectoral fin. These fishes are remarkable for the sound or grunting noise they make when captured; hence the French commonly call them "grondeus."

The red, or cuckoo gurnard, (Trigla cuculus,) so called from the similarity of the sound which it makes, when taken out of the water, to that of the cuckoo, is rery common on the British coasts. Like the rest of the species, it swims near the bottom, and feeds on crustacea, and when captured is very temacious of life. Be- 
sides the mailed appearance of the head, the gurnards are remarkable for the ample development of the pectoral fins, which sprad like a fan; in the flying fish (Trigla volitans, Linn.; Dactylopterus volitans, Cuv.) the amplitude of the fins is extreme. The red gurnard is excellent for the table, but seldom exceuds twelve or fourteen inches in length; it is in the greatest perfection during the winter months. This fish is mostly taken in trawl nets, as it swims low; it will, however, bite freely, and may be caught by means of hand-lines, the hooks being baited with any silvery shining fish, as a piece of the sand-launce.

Another species, the sapphirine gurnard, (Trigla tirundo,) is equally common, and exceeds the preceding in size, often measuring from eighteen inches to two feet in length. Its flesh is excellent when properly cookednamely, stuffed, roasted, and served up with rich sauce or drawn gravy. On the boards of the fishmongers' shops this fish may be commonly seen, with its large pectoral fins spread out or tied together over its head, giving it a curious appearance. The general colour of this species is a brownish red; the inner surface of the pectoral fins are of a fine blue; the head is large and flat. This fish is taken by means of 
the trawl net, in deep water; this net is long and conical, being from sixty to seventy feet in extent, with a square mouth of eighteen feet in breadth; it is dragged along by means of a rope, from a sailing-boat of ten or twelve tons' burden; in some parts, howerer, the trawling nets used are far larger, and the vessels are of seventy or eighty tons' burden, and cutter-rigged.

To the family of hard-cheeked fishes belongs that well-known little tenant of rivers and rivulets, the bull-head, or miller's thumb, (Cottus gobio,) common over the whole of Europe, and noted for hiding itself among loose stones, in the bed of the bubbling stream. Two allied species, the sea scorpion (Cottus scorpius) and the father-lasher, (Cottus bubalis,) with its head armed with spines, are common on our coast. Here also must be placed the sticklebacks, (Gasterosteus,) of which seven species are British, inhabiting lakes, brooks, ditches, and the sea, around our shores. One species, however, the fifteen-spined stickleback ( $G$. spinachia) rarely ascends rivers, and may be regarded exclusively as a salt water fish.

The sticklebacks are remarkably rapid and prompt in their movements, and dart along with great celerity. They feed upon insects, small worms, and the eggs of fishes. One of 
the most common, and the smallest, is the rough-tailed stickleback ( $G$. trachurus.) It seldom exceeds two inches, or two inches and a half in length, and abounds in all our ponds and brooks. A writer in the Magazine of Natural History gives the following description of its manners in captivity, in a tub or wooden vessel: "When a few are first turned in, they swim about in a shoal, apparently exploring their new habitation. Suddenly one will take possession of a particular corner of the tub, or, as will sometimes happen, of the bottom, and will instantly commence an attack on his companions. If any one of them ventures to oppose his sway, a regular and most furious battle ensues; the two combatants swim round and round each other with the greatest rapidity, biting and endeavouring to pierce each other with their spines, which on these occasions are projected. I have witnessed a battle of this sort which lasted several minutes, before either would give way; and when one does submit, imagination can hardly conceive the vindictive fury of the conqueror, who, in the most persevering and unrelenting way, chases his rival from one part of the tub to another, until fairly exhausted with fatigue. They also use their spines with such fatal effect, that, incredible as it may 
appear, $I$ have seen one, during a battle, absolutely rip his opponent quite open, so that he sunk to the bottom and died. I have occasionally known three or four parts of the tub taken possession of by as many other little tyrants, who guard their territories with the strictest vigilance, and the slightest invasion invariably brings on a battle. These are the habits of the male fish alone; the females are quite pacific, appear fat as if full of roe, and nerer assume the brilliant colours of the male, by whom, as far as I have observed, they are unmolested." This species, and two others, have three sharp dorsal spines, but the present has the sides throughout their whole length defended by a series of vertical bony plates, forming a coat of mail; in the two others, the sides are only more or less partially defended. In some places, sticklebacks are so numerous that they are caught in order to be strewed over the land by way of manure.

Another family is termed Sciminide, or that of the maigres; and we may talke that celebrated fish, the maigre, (Sciana aquila,) as an example. This fish can scarcely be termed British, its appearance on our coast being accidental. It is must abundant along the southern side of the Mediterranean, but is taken off the 
shores of Spain, France, and Italy. At Genoa, it is termed fegaro, and at Nice, figou and vanloo. The maigre is gregarious in its habits, swimming in shoals, which utter a purring noise so loud as to be heard from a depth of twenty fathoms; and from this circumstance, the fishermen are often enabled to take several in their net with certainty, their noise betraying their exact locality. Their capture, however, is not a very safe or: easy task, for the maigre is from three to six feet and upwards in length, very strong and resolute, and it struggles with the utmost desperation, knocking the men about, till one of them can manage to strike it a heavy blow on the head, and so deprive it of life. "Rondeletius," observes Mr. Yarrell, "calls this species peis rei," (royal fish.) It appears always to have been in great request witl epicures; and as, on account of its large size, it was always sold in pieces, the fishermen of Rome were in the habit of presenting the head, which was considered as the finest part, as a sort of tribute to the three locai magistrates, who acted for the time as conservators of the city." It is the umbrina of the ancient Romans. The umbrina is of a general silvery grey, inclining to brown on the back, and pure silver * It is termed peisrey, in Languedoc. 
on the under parts; the fins are reddish. There are two dorsal fins.

An allied species, the bearded umbrina, (Umbrina vulgaris,) with a short barbuie at the tip of the lower jaw, inhabits the same seas as the maigre, and is also celebrated for the excellence of its flesh. It is, however, much smaller than the latter, seldom exceeding two feet in length. It is corered with large scales. The general hue of the body is yellowish, with oblique lines on each side, from the back downwards and forwards of silver and blue.

To a family called Sparide, or the seabreams, belongs the red gilt-head, or common sea-bream, (Pagellus centrodontatus,) a common fish in the Mediterranean, and tolerably abundant on the western and southern coasts of England, and on the adjacent coasts of France. It occurs also on many parts of the Irish coast. During the summer and autumn, it is frequently taken by the Hastings fishermen, and may be seen in the fish-market. It is, however, in but little request for the table. In this fish, the teeth in front are conical, slender, and mumerous; the others are numerous, stout, rounded, and in close array, consequently they are well adapted for masticating sea-weeds, and 
crushing crabs and shell-fish, on which the sea-bream chiefly feeds.

The general colour of this fish is reddish, tinged with grey, passing into golden grey on the sides, and white underneath. At the origin of the lateral line, behind the edge of the gill covers, is a dusky patch, consisting of closely set spots or prickles. Two narrow stripes on each side behind the head meet above in the central line, and faint longitudinal bands run along the sides of the body. Pectoral fins and tail red, the other fins brownish. The young fish, called chads, are destitute of the lateral dusky spot. This fish breeds in winter, and during the spring and summer shoals of chads, about six inches in length, abound along our coast.

Passing over several other fishes of the bream family, we come to that termed Scomberide, of which that well-known and beautiful fish, the mackerel, or mackarel, (Scomber scombrus,) is an example. We need say nothing of the dazzling effulgence and elegant markings of this fish, when fresh from the sea, nor of the excellence of its flesh for the table.

The mackerel abounds in the seas of Europe, but at certain seasons approaches the shallow water near the shores, collected together in vast 
shoals, the great olject being the deposition of the roe or egrs, in places suitable for the development of the young. As a general rule, fishes leave the deep water at the breeding season for shallower spots, where the influence of the sun and light extends to the bed of the water; and when the spawning season is over, they again retire to the deep. The mackerel visits our shores at different times, earlier or later in different parts of the coast. Shoals often appear on the shores of IIampshire and Sussex in March, or even the early part of February; but the great harrest is in May and June. At Hastings, it is observed that the shoals of mackerel follow in the train of clonds of small fish, called the mackerel mint, which Mr. Yarrell suspects to be the young of the sprat. On these, and on the fry of other fish, the mackerel subsists.

The arrival of the mackerel shoals produces no little bustle and excitement in the rarious fishing-towns of our coast-every boat's crew strives to he the foremost in exertion, for the first cargoes are of the highest value. All is animation-the arrivals and departures of boats give life to the port, nor are the men on shore less occupied and active than the fishermen in the offing. The following extract from 
Mr. Yarrell's admirable work will serve to show the causes of the bustle and excitement at this juncture :-

"In May, 1807, the first Brighton boat-load of mackerel sold at Billingsgate for forty guineas per lnundred-seven shillings each, reckoning six score to the hundred; the highest price ever known at that market. The next boat-load produced but thirteen guineas per hundred. Nackerel were so plentiful at Dover, in 1808 , that they were sold sixty for a shilling. At Brighton, in June of the same year, the shoal of mackerel was so great, that one of the boats had the meshes of her nets so completely occupied with them, that it was impossible to drag them in; the fish and nets, therefore, in the end sank together; the fishermen thereby sustaining a loss of nearly $£ 60$, exclusive of what the cargo, could it have been got into the boat, would have produced. The success of the fishery of 1821 was beyond all precedent. The value of the catch of sixteen boats from Lowestoft, on the 30 th of June, amounted to $£ 5,252$; and it is supposed that there was no less an amount than $£ 14,000$ altogether realized by the owners and men concerned in the fishery of the Suffolk coast. In March, 1833, four Hastings' boats on one day brought on shore 
ten thousand eight hundred mackerel, and the next day two boats brought seren thousand fish. Early in the month of February, 1834, one boat's crew from Hastings cleared $\mathfrak{f 1 0 0}$ by the fish caught in one night, and a large quantity of very fine mackerel appeared in the London market in the second week of the same munth. They were cried through the streets of London three for a shilling, on the 14th and 22nd of MIarch, 1834, and had then been plentiful for a month. The boats engaged in fishing are usually attended by other fast sailing ressels, which are sent away with the fish taken. From some situations these ressels sail away direct for the London market; at others, they make for the nearest point from which they can obtain land-carriage for their fish. From Hastings and other fishing towns on the Sussex coast, the fish are brought to London by vans, which travel all night."

Different modes of fishing are employed in the capture of mackerel; one mode is by means of drift nets united together, which hang in the sea perpendicularly about twenty feet deep, stretching out like a curtain for a mile or mile and a half. The meshes of such nets are large enough to admit the entrance of head, gills, and pectoral fins, but too small to permit the rest of the body 
to pass. This long series of nets is let down in the evening, and usually not drawn up till the morning; the shoals roving in darkness through the water strike the meshes of fine twine, and as the fishes rush impetuously along, multitudes become firmly fixed, and are secured when the nets are hauled up by means of a capstan on deck. On the coast of Cornwall, a long deep net, with small meshes, managed by two boats, is brought round so as to inclose the shoal, or at least a large portion of it, and when the circle is made, the men draw it together at the top and bottom, and the fish thus confined are either hauled on deck, or, where the circun. stances will admit, drawn up on the beach.

Mackerel bite freely at a bait, and numbers are taken by the hook; a slip of fish and a bit of red leather, or of red cloth, are among the baits commonly used; the line is sunk by means of a plummet, with a portion free beyond the plummet, at the end of which is the hook; the boat is carried forwards by the breeze, the plummet hanging at a proper distance above the bottom of the water keeps the line steady, but trails after it the baited hook, which the fish dart at to seize; in this manner, if the breeze be smart, and the weather gloomy, two men will take from five or six hundred to a thousand 
in a single day. When taken out of the water, the mackerel dies almost instantly. Few of these fishes are salted in England, but in France great numbers thus prepared are made use of. The spring fishing-boats carry out salt with them for this purpose, and cure the fish on board. Young mackerel of the year are called shiners; excluded from the egg in May or June, they increase rapidly in size, and by the middle of autumn measure from four to six inches long; on the approach of winter they retire to the deep water.

There is a larger species, termed the Spanish mackerel, (Scomber colias,) which occasionally visits various portions of our coast, especially that of Cornwall, but the fishermen take no notice of it, as it is in no estimation.

A large species of the mackerel fumily, namely, the far famed tunny, (Thynnus vulgaris, ) common in the Mediterranean, occasionally visits our coast, and a few from time to time are captured, and sent into the market for sale.

The tunny attains to a considerable size, and though small specimens, of three or four feet in length only, are most usually taken in our seas, yet specimens of ten, fifteen, and eighteen feet in length are not uncommon in the Mediterranean. "This fish," says Cuvier, "may be re- 
garded as constituting a portion of the wealth of Provençe, Sardinia, and Sicily;" the tunny fishery, as in the days of antiquity, is most important, and its flesh maintains its pristine reputation.

In May and June, the tunny, in vast shoals, leaves the deep water, and approaches the shore, which it skirts along, seeking for convenient breeding places; and now along the coasts of Languedoc, Provençe and Sicily, begin the fishery, and all is animation and excitement. Two modes are employed. On the signal being given, by a sentinel stationed for the purpose, of the approach of a shoal of these valuable fishes, and who at the same time indicates its course, a number of boats, under the command of a leader, station themselves so as to form part of a circle, and join their nets, adding more and more nets as may be required, till the terrified fish are hemmed up in an inclosure, which is gradually drawn towards the shallow water, near the edge of the shore. Here a large net, with a cone-shaped tunnel, is made use of to receive the fish, and is dragged upon the beach with its heavy burden. The young and small tumnies are, however, taken out in the arms of the fishermen, and the. large oues are killed with poles. 
The other mode is called in Italian tomaro, and in Provençe madrague. Parallel with the shore, along which the shoals take their course, a net, extending for a mile, is fixed vertically by means of corks along its upper margin, and weights along its lower edge, and lept in its position by anchors; it thus forms a sort of netted wall; from this wall to the coast are drawn numerous cross nets, dividing the space into many chambers, having narrow openings of communication on the land side. Proceeding along, between the long net wall and the shore, the fishes are suon stopped by one of the cross nets; instead of turning back, they enter into the chamber by the narrow opening left for them; having entered, they are driven by the fishermen from chamber to chamber till they enter the last, which is floored with a strong net, so fixed as to be capable of being raised or lowered. About this chamber of death, the fishermen, armed with long poles, collect in boats, and the unequal conflict begins. The net flooring is raised; the floundering of the devoted tunnies, the shouts of the men, the splashing of the long poles, as they rain blows on the crowded fish, constitute a scene which forms one of the greatest amusements of the people of Sicily, and the southern 
coast of France. The flesh of the tunny is red, and as firm as veal; it is dressed in various ways ; slices are boiled or fried; it is made into ragouts; it is put into pies or pâtés, celebrated by the epicures of France; it is converted into a sort of pickle, with salt and oil, and this preparation, under the term of thon mariné, is eaten cold. It is also cured by being cut into slices and packed in barrels with pounded salt.

In its general figure the tunny resembles a huge mackerel, but with a shorter head. The colour of the upper parts of the body is dark blue; numerous large scales of a paler colour form a corslet around the thorax or chest; the sides of the head are white; the under-parts are grey, variegated with silvery white markings. The first dorsal fin, the pectoral and ventral fins, are black; the rest pale pink, with a silvery tinge; tail fin dusky; the sides. of the tail are carinated, crooked, or bent like the keel of a ship. Several allied species, as the alicosti, the tonine, are found in the Mediterranean. The bonito of the tropics belongs to the same genus.

There is another fish taken in the Mediterranean with the tunny, distinguished as the representative of a distinct genus only by the 
enormous length of its pectoral fins. This fish is called $L a$ Germon in the Basque language, and Alalonga by the Italians, (Orcymusalalonga, Cuv.) In spring and summer, vast shoals of this fish enter the Gulf of Gascony, where immense numbers are regularly taken. This fish often weighs eighty pounds; its flesh is more white than that of the tunny. It is of a dark blue above, passing into silvery on the under surface.

On various parts of our coast, especially the southern, a fish called the scad or horse-mackerel, (Caranx trachurus,) is often very abundant, anil occasionally seen in enormous shoals. In July, 1834, as $\mathrm{M}$ r. Yarrell informs us, most extraordinary shoals passed up the channel along the coast of Glamorganshire; their passage occupied a week, and they were evidently in pursuit of the fry of the herring. The water appeared one dark mass of fish, and they were caught by cart-loads, and night eren be baled out of the water by the hands alone.

In the west of Cornwall, scad are caught and salted like mackere], for winter consumption; but in other places the fishermen do not deem them worthy of any especial notice, nor do they often appear in the London markets, as they are very inferior to the mackerel; occasionally, however, they are to be purchased. 'The scad 
averages twelve or fourteen inches in length; the body is covered with small scales, with the exception of the lateral line, which exhibits a series of large broad scales, producing a singular appearance; those more especially of the posterior half of the body have a central ridge or keel, ard each overlapping margin in succession is pointed. 'The appearance is as if a stripe of plate-armour ran along each side of the body. The general colour above is dusky olive, with iridescent green, and a bluish wavy gloss; the sides of the head and the surface below the lateral line are silvery, with waved reflexions; a large spot on the gill-covers and the throat are black; upper fins dusky; lower fins whitish.

That singularly compressed and deep fish, the Joln Dory, of epicurean renown, belongs to the present family. The derivation of the name of this species (Zeus faber, Linn.) is doubtful ; the Italian fishermen term it $I l$ janitore, * or the gatekeeper; the French Jaune dorée, (gilded yellow,) or simply Le Dorée, or Pois-

* This name is an allusion to St. Peter, who took the tribute money from the fish at the command of our Lord, and who, in Roman Catholic countries, is supposed to bear the keys of heaven; a black spot on each side the fish is superstitiously imagined to indicate the pressure of the apostle's thumb and finger-but the ladklock may on this accucut put in a claim. 
son-Saint-Pierre. The term may be a corruption of either janitore or jaune dorée. Pennant calls this fish the Doree. To the ancients it was known by the name of Zens, or Jupiter.

On our coast, the dory is found along Hampshire and Sussex, Cornwall and Devonshire, occasionally it is taken off Yarmouth, and more rarely still further north. It visits some part of the Irish coast, but not, we believe, in abundance. It is common around the French and Spanish coasts, and in the Mediterranean. It is said to follow the shoals of pilchards, on which it preys; it also devours small cuttle-fish. Autumn and winter are the principal seasons in which it is taken; its flesh is firm, and regarded as improved by keeping for a few days.

As its form sufficiently indicates, the dory is by no means rapid in its morements; it wanders leisurely through the deep water, often drifting with the current, though it can, no doubt, exert itself rigorously enough when prompted by its appetite.

The head of this fish is large and inelegant; the body is much compressed, and of an oval form ; the spines of the first dorsal fin are projecting, and accompanied by long filaments, and there are spinous scales along the dorsal and ventral edges. The mouth is armed with 
numerous teeth, and capable of great protrusion. The general colour of the body is olive brown, tinged with golden yellow, and with reflexions of blue and silvery on each side; a little behind each gill-cover is a circular mark of black.

To a family termed Mugilidie belongs the grey mullet, (Nugil capito,) a common fish on our coasts, and on those of the adjacent continent. Along the shores of Essex, Kent, and Sussex this fish abounds, extending to Cornwall aud Devonshire. It prefers shallows near the shrore to the deep, and is extremely active and vigorous, leaping with great address; it thus often throws itself over the head-line of the sweep-net which surrounds it, and so makes its escape. It is not, however, to the salt water that the grey mullet confines itself; it enters the mouths of rivers, advancing above the tideway into the fresh stream, and has been found up the Arun twenty miles from the sea. An Arundel mullet is celebrated. This fish will indeed not only live, but thrive in purely fresh water; we learn from Mr. Yarrell that Mr. Arnold put a number of the fry of the grey mullet into his pond at Guernsey, which covers an area of about three acres, and that, after a few years, fish weighing four pounds were taken, which proved to be fatter, deeper, and 
heavier for their length than sthers obtained from the sea.

Mr. Couch says: "The grey mullet selects food that is soft and fat, or such as has begun to suffer decomposition; in search of which it is often seen thrusting its mouth into the soft mud, and for selecting it its lips appear to be. furnished with exquisite sensibility of taste, It is indeed the only fish of which I am able to express my belief, that it usually selects for food nothing that has life, although it sometimes swallows the common sand-worm."

The grey mullet breeds at Midsummer. In its form this fish is nearly cylindrical; the scales are large; the dorsal fins are two, and widely separated, fin-rays of the first sninous; the under-jaw is produced into an elevated angular point, received into a corresponding notch in the centre of the upper jaw; nostrils double. General colour above blueish grey, sides and under parts silvery, with several longitudinal dusky lines. Two additional British species are described, both very raxe, namely, the thick-lipped grey mullet, (Mugil chelo,) and the short grey mullet, (Mugil curtus, Yarrell.)

Along some parts of our southern coast, and especiaily that of Sussex and Iampshire, and 
also of Devonshire and Cornwall, a fish called the atherine, or sand-smelt, (Atherina presbyter,) sometimes confounded with the true smelt, * and sold as such at Southampton, is very abundant. It possesses in a slight degree the cucumber snell of the true smelt, and though far inferior to the latter, is nevertheless when in full roe a delicate little fish; in spring it is in perfection, but great numbers are caught during the winter months, and throughout this season Brighton and other towns on the same line of coast are plentifully supplied.

The atherine prefers quiet sandy bays, and tranquil water to the turbulent deep, and in stormy weather numbers are occasionally washed on shore.

Various modes of fishing are adopted in the capture of this silvery little fish, but the most common way is by means of a sweep-net with small meshes, by which the shoal is inclosed. In the atherine, the first dorsal fin has eight spring rays, the second one spring ray, and twelve cartilaginous. In the true smelt, the second dorsal fin is rayless and fleshy as in the salmon. The general colour of the atherine along the sides is of a glistening silvery white. The upper part of the back and lical are

* The true smelt belongs to the salmon and trout samily. 
sprinkled with small blackish spots. Conmon as this fish is, it is not very frequently brought to the London market, which is abundantly supplied with the true smelt.

Occasionally in the fish-markets or shops in London are to be seen specimens of a ferocious looking fish, called the wolf-fish, sea-wolf, or sea-cat, (Anarrhichas lupus.) It belongs to the family of the Gobies, (Gobioüla.)

This strange repulsive fish has an elongated body, covered with small scales; a long dorsal fin extends down the whole of the back. There are no ventral fins, and the pectorals are comparatively small, the head short and rounded, and the markings of it, together with the position of the glaring eyes, and the long sharp curved front teeth, give a fierce cat-like expression. The back teeth and those of the palate are in close array, thick and tubercular, or rounded, and well adapted for crushing crabs, lobsters, and shell-fish. One of these fishes, of about four feet long, the writer lately saw in London. It attaius, however, to the length of six or eight feet, or even more. The wolf-fish is a native of the high northern seas, and is common along the shores of Greenland and Iceland; yet it not unfrequently appears on different parts of our crast, espccially those of Scotland, Yorkshire, 
etc., and it is far from being uncommon among the Orkneys.

Notwithstanding its repulsive appearance, the flesh of this fish is a delicacy; in the countries of Norway, Sweden, etc., the head and the thick slimy slin are removed previously to any culinary operations, and the latter is converted into serviceable bags, and other articles.

The wolf-fish is really as ferocious as its aspect indicates; when inclosed in a net, either by accident or by the temptation which the imprisoned crowd offers to its voracity, it makes, on discovering its peril, the must desperate efforts for escape; it rushes against the meshes, endeavouring to break through, it tries to rend the cordage, and often succeeds, and should it fail, it fights and snaps with tremendous fury, even when hauled on board the boat, struggling till the blow of a heavy handspike on the head deprives it of motion or existence.

From the length of the body the fish swims with an undulatory motion, and with great vigour; the female deposits her eggs near the shore, in June. The general colour of this tyrant of the seas is brownish grey, with darker vertical bands on the back, and intermediate spots; the under surface is whitish; a trian- 
gular, dusky mark occupies the top of the head, pointing between the eyes.

Another ferocious fish, the type of a distinct family, having the pectoral fins feet-like, is often found on onr shores; we allude to the angler, or fishing-frog, (Loplizus piscatorius.) In this hideous fish, the head is of enormous size, and depressed, or flattened; the mouth is of rast width and capacity, but the body is slender; the eyes are placed with an upward aspect, on the top of the liuge broad head; the jaws, the palate, and tongue are armed with long, sharp, recurved teeth; the edge of the lower jaw is fringed all round. On the top of the head are three long filaments, in the median line; of these two are seated just abore the muzzle, the other rises from the back of the head. These elongated filaments are supported by bone, and are morable in all directions, especially the first, which, tapering like the finest fishing-rod, ends in a broad flattened silvery tip, abundantly supplied by nerves. 'The pectoral fins are broad and thick, and serve the office of hind feet, for the rentral fins, palmate in form, are placed far anterior to them on the body.

The angler is insatiably roracious, but it is a slow swimmer; it is, in fact, furmed for taking 
its prey in ambush. It reposes on the soft mud or sand, in some favourable lurking-place, and, stirring up the mud with its jectoral fins, thus obscures itself in a murky cloud, beyond which appear its long filaments, and especially the first, with its glittering tip, offering an attractive bait to other fish. Thus stationed, quietly the angler expects his victim. On rove the shoals of fish, eager in quest of food; they pass one after another in succession, till at length one espies the bait; forward the fish darts, either to examine or seize the anticipated prize, but at that instant, aided by the broad feet-like pectoral fins, up springs the watchful angler, and seizes his unwary victim. Such is the success of this voracious tyrant, that the fishermen, who often capture it in their nets, examine its stomach, and sometimes obtain from it a considerable number of serviceable fish, yet alive, which it had just engulphed; nay, even when inclosed in the net, it continues to the last to devour its fellow-prisoners. It is not, howerer, always that the angler thus obtains his food; he is sometimes seen floating on the surface, ready to snap at whatever prey comes within his sudden dart. Sometimes this fish is taken by means of a baited look in mid-water; but it is most usually captured by 
means of the net, which occasionally incloses more than one at a sweep.

The angler measures from three to five feet in length ; its colour is a dirty brown. It is found in most of the seas of Europe, and may often be seen in the fishmongers' shops.

Several species of fish, called wrasse, or rockfish, (Fam. labride ,) are common on our coast, and those of the adjacent continent. They are remarkable for the beauty of their colours, their thin large scales, their great thick lips, and their numerous and conspicuous teeth. They generally haunt rocky shores, dwelling in deep guilies between masses of rock, and under the covert of the long fronds of sea-weed. They feed on small crabs, and other crustacea, but are in no request for the table. 


\section{CHAPTER IV.}

FISHES WITH SOFT FIN-RAYS, AND THE VENTRAL FINS REMIOTE FROM TIE PECTORAL.

Tue second order of osseous fishes is termed Malacopterygii, that is, fishes having the fin-rays almost universally flexible, excepting that in some, as the carp, the first and second ray of the dorsal fin, and first ray of the opposite fin, are bony and strong.

In the first section, termed Abdominales, the ventral fins are suspended under the abdomen, considerably beyond the pectoral fins.

To this subdivision belong the Cyprinidae, or family of the carps, of which we maly take the well-known common carp as an example. T'he carp, so abundant at the present day in the ponds, lakes, and sluggish rivers of our island, is not an aboriginal of England; we know not, however, at what period it was introduced, nor from what part of the continent, but most probably from France or Italy, and certainly before 
the fifteenth century, sinee it is noticed as a dainty fish in the "Buke of St. Albans," printed in $14 \$ 96$. Perhaps we owe its introduction to some of the Norman settlers here, soun after the conquest. In Sicotland, in Tiussia, and cther cold parts of Europe, the carp either refuses to breed or does not even exist. In Austria and Prussia, howerer, where this fish is in great request, as, indeed, are many other fresh-water fishes, it abounds in ponds and prescrres, which are let by the owrers, at considerable profit. In Ireland, it is believed that carp were not introduced till the tiraes of James I. At whatever time, or under whatever superintendence the carp became naturalized in our country, it soon thronged the fish-ponds attached as needful appendages to the monasteries, and thence began to be considered as one of the delicacies of the table, though the dry fibrous flesh of this fish is, in our opinion, anything but agreeable. However, if our readers will follow Walton's directions, they may render it palatable: "Take a carp, alive if possible, scour him and rub him clean with salt and water, but scale him not; then open him, and put him, with his blood and liver, which you must save when you open him, into a small pot or kettle; then take sweet marjoram, fiyme, and parsley, 
of each lualf a handful, a sprig of rosemary and another of savory. Bind them in two or three bundles, and put them to your carp, with four or five whole onions, twenty pickled oysters, and three anchovies; then pour upon your carp as much claret wine as will only cover him, and season your claret well with salt, clores, and mace, and the rinds of oranges and lemons; that done, cover your pot and set it on a quick fire, till it be sufficiently boiled; then take out the carp, and lay it with the broth on a dish, and pour upon it a quarter of a pound of the best fresh butter, melted and beaten with half a dozen spoonfuls of the broth, the yolks of two or three eggs, and some of the herbs shred. Garnish your dish with lemons, and so serve it up, and much good may it do you."

Worms, the larve of insects, and the tender leaves of aquatic plants, constitute the food of the carp; they will also eat bread-crumbs, and in small ponds may be rendered very familiar. During the winter, these fish retreat to deep holes under banks, and bury themseives in the mud. Fishing for carp is a work of patience. This fish attains to a great age, even to a hundred or a hundred and fifty years, and often acquires an enormous size. Mr. Yarrell states, 
that in 1793 , at the fishing of the large piece of water at Stourhead, where a thousand brace of kiling carp were taken, the largest was thirty inches long, upwards of twenty-two broad, and weighed eighteen pounds. "At Weston Hall, Staffordshire, the seat of the earl of Bradford, the painting of a carp is preserred, which weighed nineteen and a half pounds;" it was caught in a lake of twenty-six acres, called the White Sitch, on the estate. Other instances of huge carp are on record.

The carp, with its large scales resplendent with golden brown, is too well known to need a description. It is extremely prolific, and is so tenacious of life, that it may be kept for days on a basket of moss, freely saturated with water. There is a small barbule at each corner of the mouth.

An allied naturalized species, the Crucian carp, or Prussian carp, (Cyprinus gibelio,) is found in some of our sheets of water, and in various parts of the Thames. This species has no barbules at the mouth; it is extremely beautiful, being of a brilliant golden metallic lustre. In general habits, it agrees with the preceding species.

Another species, too well known to be described, is the beautiful gold carp, or gold-fish, 
(Cyprinus auratus,) originally brought from China. It is commonly kept in vases for ornament, and also in ponds and tanks in pleasuregrounds, where, if thoroughly sheltered from the cold, it breeds freely. We have known engine-ponds, into which warm water from the steam-engine flows, keeping up a milk-warm temperature, thronged with these beautiful fishes. At the Cape of Good Hope, and in the Mauritius, this fish is completely naturalized. The young of this species are at first black, or very dusky, and only acquire their golden tint by degrees. Small tanks of wood in hothouses, or conservatories for aquatic plants, may be often seen thronged with these fish, where they freely breed. They are easily rendered familiar.

In many of our rivers, and especially in the Thames, a fish termed the barbel (Barbus vulgaris) is very common. It is said to derive this name from its four barbs, or barbules, on the upper lip. This fish is of handsome form, and grows to a considerable size, occasionally weighing from ten to fifteen pounds.

The barbel is gregarious in its habits, and is swift and vigorous. During the summer, these fish frequent the shallower parts of the river, and the female, in May or June, deposits her 
eggs in the gravel. Though very shy, they are said to be extremely sportive, darting with the utmost ease up the most rapid current. Worms, the larre of insects, and small fishes, are their ordinary food, and they love to lurk anong weeds, digging in the mud with their nose, probably in quest of prey On the approach of winter they seeis the deeper parts of the river, and shelter themselves in looles under the bank, or the wood-work of locks, dams, or weirs, and similar situations. In severely cold weather, they sink into a state of partial torpidity, and may be captured by means of a landing-net, without attempting to escape.

The colour of the barbel above is olive brown, passing into jellowish green on the sides; the gill-covers are tinged with brouze, the fins of the lower parts are flesh colour.

Among the smaller fishes of our sandy, or gravelly streams and rivers, we may notice that pretty little fish the gudgeon, which, were its size equal to the delicacy of its flesh, would be in considerable request. As it is, numbers are taken in nets by the Thames fishermen, and kept alive in well-boats for sale. They may also be frequently scen alive in stone or leaden tanks in the shop's of the fislumonecrs. 
The gudgeon is gregarious, wandering about in shoals, and feeding upon worms, the larvæ of insects, and the eggs of fishes. Few fish bite more freely; two or three dozen, indced, may be often taken in the course of an hour. This fish seldom exceeds five or six inches in length. As it is well known, no detailed description is necessary. It breeds in May, depositing its eggs among loose stones and gravel.

The deep pits, ponds, lakes, and still, sluggish rivers of England, (and also of some few parts of Scotland and Ireland,) present us with the tench, (Tenca vulgaris,) a deep-bodied slimy fish, with minute seales, and decidedly superior for the table to the carp. This fish appears, like the carp, to have been at some period introduced and naturalized in our island, but we bave no data respecting it. The most congenial abodes of this fish are deep drainage ponds of soft water, with a muddy bottom, having a luxuriant border of aquatic plants, with abundance of pond-weed throughout. In such pits or ponds, it thrives and multiplies greatly, often attaining to a considexable size, and the weight of two or three pounds. Occasionally it is said to taste rankly of some kind of weed or mud; but specimens of this fish, from some of 
the muddiest ponds in Essex, which a few months since were placed before the writer at table, were of very superior flavour, and finely grown. Their colour, for he saw them when alive, was very dark, with a pink tinge about and under the pectoral fins.*

The tench breeds in June and July; of its fecundity we may form some estimate, when we learn from Bloch, that in a fish of four pounds' weight he found nearly three hundred thousand eggs composing the roe. Nothing is more easy than to stock appropriate ponds with this excellent fish, to which the carp is most decidedly inferior. The male fish is at once distinguishable from the female, by the large size of the ventral fins; the proportion of the males should be double to that of the females, and well-grown specimens should be selected. The food of the tench consists of worms, larvæ, and various vegetable matters. During the winter, these fishes retire to holes and snug recesses, and stir but little, indeed, they are not among the most active of their tribe at any time; sometimes they get blocked up in their retreats, but this is of little consequence, for such is

* It is remarkable that Mr. Yarrell quotes a similar statcment by Dauicl, respecting tench taken at Munden Hall Fleet, in Fissex, 
their vitality, that as long as they are bederved with water and their gills kept wet, they will live and feed on what chance throws in their way. Daniel, in his Rural Sports, gives a curious confirmation of these facts, which is quoted by Mr. Yarrell, and may well be repeated here, as it is on undoubted authority. "A piece of water, which had been ordered to be filled up, and into which wood and rubbish had been thrown for years, was directed to be cleaned out. Persons were accordingly cmIloyed; and almost choked up by weeds and mud, so little water remained that no person expected to see any fish, except a few eels; yet nearly two hundred brace of tench of all sizes, and as many perch, were found. After the pond was thought to be quite free, under some roots there seemed to be an animal, which was conjectured to be an otter; the place was surrounded, and on opening an entrance among the roots, a tench was found of most singular form, having literally assumed the shape of the hole in which of course he had been for many years confined. His length from eye to fork was thirty-three inches, his circumference almost to the tail was twenty-seven inches, his weight eleven pounds nine ounces and a quarter; the colour was also singular, his belly 
being that of a char, or vermilion. This $\mathrm{ex}-$ traordinary fish, after having been inspected by many gentlemen, was carefully put into a pond, and, at the time the account was written, twelve months afterwards, was alive and well." Not only then did this fish live in his moist prison, but grew to an enormous size. The tench is too well known to require a particular description.

In many of our large rivers or lakes, and in some of our canals and slow rivers a tish called the bream, or carp-bream, ( 16 remis breana,) is very abundant; it inhabits the lakes of Cumberiand and those of Ireland, and is common in the southern and central parts of the European continent.

Walton says: "The French esteem this fish highly, and to that end have this prorerh, $\mathrm{He}$ that hath breams in his pond, is able to bid his friend welcome. And it is noted that the best part of a bream is his belly and head." This last observation may be taken as a tacit admission that the hream does not merit the praise bestowed upon it; in fact, its flesh is insipid and full of little bones-but French coolsery may prohably render it palatable.

The bream is very prolific, and in large lakes affords an aloundant supply of food to 
pikes, and other voracious fishes. The female deposits her eggs in May, and, according to Bloch, there are one hundred and thirty thousand in the roe of a well-grown individual. In some parts of Ireland, where breams are rery abundant and very large, sometines weighing ten or twelre pounds each, the fish are taken in large quantities and dried, in which state they are acceptable to the peasantry. The bream has neitber bony rays on any of its fins, nor barbules about the mouth; its body is deep and compressed; its general colour is yellowish white, often with a tinge of brown. A distinct and smaller species, of a silvery white, inhabits some of our rivers, as the Trent, the Cam, as well as lakes, etc. It is the white bream, or bream-flat, (Abramis blicca,) common on the continent. It is in no request for the table.

Two fishes, respectively termed the roach, (Leuciscus rutilus,) and the dace, (Lenciscus vulgaris,) are common in the rivers and lakes of the British islands and those of the adjacent continent. They are pretty silvery-sided fish, gregarious in their habits, and are fond of deep quiet spots, or still nooks in the river, mill-clams, and similar situations. These little fishes are not in much estimation for the table, yet their flesh is delicate, and in the best degree of per- 
fection in autumn. We need not describe these fishes, but may be permitted to point out the obvious differences between them.

The roach is a deeper fish than the dace, with a longer dorsal fin, and a lateral line sweeping more decidedly downwards from the head. The dorsal and caudal fins are pale brown, tinged with red, the pectoral fins are orange red, the others bright red. In the dace, the dorsal and caudal fins are pale brown, and all the others white, with a tinge merely of red.

In the Mersey, and some of its tributary streams, a fish termed the graining (Leuciscus Lancastriensis, Yarrell) is found. It was noticed by Pennant, who observes, that it in some respects resembles the dace, but yet is a distinct and perhaps new species. For a clear history of the fish, till lately in obscurity, we are indebted to Mr. Yarrell. He informs us, that " in its habits and food it resembles the trout, frequenting both the rapids and still parts of the rivers, but is not known to exist in ponds. They sometimes, though not commonly, exceed half a pound in weight, and are much better eating than the dace." He gires the colouring as follows: top of the head, back, and upper portion of the sides, pale drab, tinged with 
blueish red, and separated from the lighter coloured parts below by a well-defined boundary line. Cheeks and gill-covers silvery white, with a tinge of yellow; fins pale yellowish white. Fin-rays, D 9. P 17.v 10. A 11. c 19.

In the Thames, and most of our larger rivers, where deep and quiet nooks afford it a congenial retreat, the chub (Leuciscus cephalus) is a common fish. It is shy and recluse in its habits, and loves the shelter of willows, and steep banks, which throw a shade over its lurking-place, so as to screen it from observation. The chub is too well known to need description.

Common in the Thames, and most of our rivers, is the rudd, or red-eye, (Leuciscus erythropthalmus, remarkable for the golden coppery tint of its general surface, and the red colour of the iris.

Another common species is the bleak, (Leuciscus alburnus,) a silvery little fish, roving in shoals; and formerly in great request, (as were also the roach and dace,) for converting small hollow glass beads into imitations of pearl. This was effected by lining their inside with the beautiful silvery pigment which gives lustre to the scales of fish; this was procured by steeping the scales, first carefully cleaned of 
slime and dirt, in pure water, to the bottom of which the pigment was in a short time precipitated.

In some of the streams of Lancashire, a fish called the azurine, or blue roach, (Leuciscus ccrulcus, Yarrell,) occurs, though perhaps not abunclantly. It was first described as a new species by Mr. Iarell, in the Liun. Trans., vol. xvii. part 1, p. 8, having been previously unknown either to British or continental naturalists, though we believe that, with the graining, it inhabits some of the Swiss lakes.

It seldom weighs more than ten or twelve ounces, rarely a pound. Its general colour is glossy slate blue, passing into silvery white beneath; fins white.

In all our clear streams, brooks, and rivers, the minnow or pink, (Lenciscus phoxinus, abounds in shoals, roving about in quest of food, now appearing in the shallows, now seeking the deeper parts, and anon scattering asunder, as some pike, trout, or perch, intent on prey, strikes the phalanx with panic. We have often watched their morements, and have frequently seen them in compact array encircle various ohjects, as a large worm or dead fish, on which they have continued to feed until disturbed on purpose; we have seen them, too, when scat- 
tered, re-assemble by degrees, and again proceed with their feast.

The colours of this little fish are exquisitely beautiful, and its movements are prompt and active. Numbers in a short space of time may be readily captured, and a good dish of fried minnows, small as the fish is, is by no means to be despised as a delicacy.

The minnow breeds in June, and the young by the middle of autumn is about three quarters of an inch in length. The adult fish seldom measures more than three inches or three and a half.

Another little tenant of our gravelly streams is the loach, (Cobitis barbatula,) remarkable for its slimy surface, and six barbules on its upper lip. This fish is in the habit of lurking under stones, where it lies perfectly concealed from observation. When disturbed it darts rapidly along, keeping, however, at the bottom of the water, and speedily availing itself of another hiding-place. The flesh of the loach, small as the fish is, (seldom exceeding four inches in length,) is very delicate, and on the continent highly prized. It was on this account that Frederick I., king of Sweden, caused this species to be brought from Germany, and naturalized in his own country. 
In the Trent, and in some of the streams of Wilts and Cambridgeshire, a very minute fish, called the spined loach, or groundling, (Botea tonia, ) is to be found. It is about two inches and a half long, and, like the loach, sceretes itself under stones. It has a decided spine just behind each nostril.

The family Esocida contains several British fishes, some belonging to the fresh water, others to the sea.

Among the former is the ferocious pilke, (Esox lucius, ) the tyrant of the lake and river.

The form of the pike indicates its great power and activity in its native element. It ploughs the water with extraordinary euergy, and darts upon its prey with the velocity of an arrow; there is a sudden flash, circle after circle forms on the surface of the water, but all is still again in an instant.

No fish is more wary and watchful than the pike; shrouded from observation in his solitary retreat, he follows with his eye the motions of the shoals of fish that wander heedlessly along, he marks the water-rat swimming to its burrow, the ducklings paddling among the waterweeds, the dab-chick and the moor-hen leisurely swimming orer the surface. He selects inis 
victim, and, like the tiger springing from the jungle, he rushes forth, seldom indeed missing his aim.

Of the daring and ferocity of this fish many authenticated instances are on record. Walton says: "Gesner relates, that a man going to a pond (where it seems a pike had devoured all the fish) to water his mule, had a pike bite his mule by the lips, to which the pike hung so fast that the mule drew him out of the water, and by that accident the mule angled out the pike. And the same Gesner observes, that a maid in Poland had a pike bite her by the foot, as she was washing clothes in a pond. And I have heard of the like of a woman in Killingworth pond, not far from Coventry. But I have been assured by my friend, Mr. Seagrave, who keeps tame otters, that he hath known a pike in extreme hunger fight with one of his otters for a carp that the otter had caught, and was then bringing out of the water." Dr. Plnt states, that at 'Trentham, Staffordshire, a pike seized the head of a swan, as she was feeding under water, and gorged so much of it that both fish and swan perished; the keepers, perceiving the swan fixed with its head under water for an unusual time, took a boat to go to the bird's assistance, but it was too late. 
Mr. Yarrell, on Mrr. Jesse's authority, says: "The present head-kceper of Richmond park was once washing his hand orer the side of a boat, in the great pond in that park, when a pike made a dart at it, and he had but just time to withdraw it." Mr. Jesse adds, that "a genileman now residing in Weybridge, in Surrey, walling one day by the side of the river Wey, near that town, saw a large pilse in a shallow creek. IIe immediately pulled off his coat, tucked up his shirt-sleeves, and went into the water to interrupt the return of the fish into the river, and to endearour to throw it out on the bank by getting his hands under it. During the attempt the pike, finding he could not make his escap'e, seized one of the arms of the gentleman, and lacerated it so much that the marks of the wound are still visible." The following anecdote is taken from one of the public papers, August 25, 1846 : "On Thursday, Mr. Collet, in company with a friend from London, were fishing at Shepperton, for barbel, when the bait was taken by a roach, which, in its turn, was instantly seized by a pike. The line was drawn in, the pilse continuing its hold upon the small fish till near the water's edge, when it suddenly leaped from its rictim and threw itself on the bank, when both pike and roach were captured. 
The pilse weighed 91bs, and, on opening it, in its stomach were found three small fish, a waterrat, and a young moor-hen."

The roracity of the pike is connected with its rapidity of growth, which necessitates an abundant supply of nutriment, and involves at the same time extreme celerity of digestion. A young pilse is recorded to reach to the length of about eight inches cluring the first year, to that of twelve or fourteen during the second year, and of eighteen or twenty inches during the third; after this its increase for sereral successive years, where stores of food are abundant, is at the rate of three or four pounds per year. Eight pikc, of about five pounds each, have been ascertained to devour eight hundred gudgeons in three weeks. Some idea from this may be formed of the havoc this fish must make in the meres, lakes, or rivers, in which it is plentiful, and of the necessity of encouraging the breeds of inferior fishes, as the bream and others, for its due maintenance. The pike not only lires to an extreme age, but attains to extraordinary dimensions. Pennant speaks of one ninety jears of age, and Gesner notices a pike taken at Inilhrun, in Suabia, in 1497, with a brazen ring attached to it, on which was inscribed in Greek characters, "I am the fish which was 
first of all put into the lake by the hands of the governor of the universe, Frederick the Second, the 5th of October, 1230." This fish must therefore have been at least 267 years old. It is said to have weighed 350 pounds.

In the lakes of Scotland and Ireland, pike weighing from fifty to seventy pounds have occasionally been taken, and Horsea. Mere, and Heigham Sounds, two large sheets of water in Norfolk, have been long celebrated for the size and excellence of their pike, and also for their abundance.

In the lakses of North America, a species of pike, called the muskanungee, grows to an enormous size, but we cannot obtain any definite measurements.

It must not be supposed that the larger pike are, the better is their flesh for the table; Walton rightly says: "Old or very great pikes have in them more of state than goodness; the smaller or middling-sized piles being, by the most and choicest palates, observed to be the best meat."

In warn and sunny weather, the pike mostly swims near the surface, and may be often seen luxuriating in the sunbeams, lulled into a sort of slumber. It is not difficult at such times to draw a wire noose, fastened to the end of a rod 
or long staff, over its head or body, and land it by a sudden jerk.

Pike are taken hy spinning or by trolling : and in large sheets of water, in Norfolls, by liggers or trimmers, that is, a baited hook attached to a line, secured to and wound round a fluat of rushes, a due portion of the line only being free, and sufficiently secured from alteration by being caught between the rushes, or in a notch of a wooden float, sometimes used instead of the rush float. This is put into the water, and when the bait is seized by the fish, the jerk disengages the line from its slight security, and the whole is unwound to the float, which latter indicates the occurrence.

The jaws and palate of the pike are most formidably armed with sharp teeth of various sizes, the form of the body is elongated, and the dorsal fin is placed far back.

The pike has various names in our language, as pickerel, luce or lucie, and, in Scotland, gedd. Pike, of small size, are often called jack.

Among the sea-fish of this family is the well-known garfish, (Bclone vulgaris,) remarkable for its elongated slender body, and long projecting jaws, tapering to an attenuated point, and armed with small teeth. The bones of this fish are green. 
In April or May, the garfish leares the deep sea, and risits various portions of our coast, and of that of continental Europe, for the puxpose of breeling. This fish is often called the mackerel guide, from the circumstance of its making its appearance a little before the shoals of mackerel ; it is taken in considerable numbers, and, during its short stay, may be seen abundantly in the London markets; its flesh, however, is but indifferent.

The garfish is very active and vigorous, and cuts through the water, generally near the surface, with great rapidity.

Occasionally an allied species, the slipper, or saury pike, (Scomberesow saums, risits our shores in shoals, generally making their appearance in Jume. It is common in the Mecliterramean, and is there a favourite prey of the tunny, which scatters the shoal as it darts anidst them, throwing them into consternation. In order to escape their foc, they leap one orer the other, to a great distance out of the water, the hindmost striving to get first in the race, and the foremost rushing for yards tonether on the surface of the water, which they scarcely seem to touch. Often does the mariner gaze on such a scene. Thousands of skippers pass the ressel, with tumnies and bonitoes in 1ull 
chase, their scales glistening in the sun; anon the pursued and their pursuers disappear in the deep-anon they return to the surface, all in confusion, but still rushing along, leaping and diving, till ont of the spectator's sight.

In form, the skipper much resembles the garfish, but the posterior half of its elongated body is stouter and deeper in proportion. Its gill-covers are silvery white, as are the sides and under parts, but the back and top of the head are of a dark blue.

We may now pass onward to another family, that of the Salmonides, or salmon tribe, of which the salmon (Salmo salar) is a well-known example.

We have already described this queen of fishes as a periodical visitor to our rivers, in which it breeds, depositing its eggs in the gravel in the winter, hoving pushed up from the estuary during the autumn, to which they again descend in the spring, and pass the latter part of the summer in the sea. It would appear, however, that the breeding season of this fish, and consequently the precise time of its visit to the upper portions of the river, are influenced by various causes, which hasten or retard the development of the roc. In Sweden, according to Artedi, the salmon do not deposit 
their eggs till the middle of summer. 'The warmth of the water may be an influencing cause. "There are two rivers" says sir William Jardine, "in Sutherlandshire, which show this late and early running (of the salmon) under peculiar circumstances. One, the Oikel, borders the county, and springs from a small alpine lake, perhaps about halt a mile in breadth; the other, the Shin, is a tributary to the Oikel, joins it about five miles from the mouth, but takes its rise from Loch Shin, a large and deep extent of water, and connected to a chain of other deep locks. Early in the spring, all the salmon entering the common mouth diverge at the junction, turn up the Shin, and return as it were to their own and warmer stream, while a rery few keep the main course of the Oikel until a much later period." *

The vignur displayed by the salmon in shooting up the most impetuous rapids is very wonderful, nor do waterfalls or cascades daunt them. Curving the body till the tail and head meet, they give a lash with all their force to the water, and spring up with amazing address. Often they miss their leap, and fall back into the river, but it is only to wait for fresh

$$
\text { * Yarrell. }
$$


strength, and more energetically to renew their attempt; thus they surmount a fall of eight or ten feet, but not always without accidents; sometimes they throw themselves out of the stream upon the rocks and stones, and so perish; and sometimes they kill themselves, by the repetition of their fruitless efforts.

Having at length arrived at their proper breeding places, shallow gravelly pools, in the pure stream, the salmon prepare for the deposition of the eggrs. At this time, the cheeks of the male become variegated with stripes of orange colour, and an orange tinge pervades the body; the lower jaw becomes elongated at its tip, by the development of a cartilaginous projection, which, when the month is closed, occupies a deep notch at the end of the snout. The female at the same time assumes a dark colour, and both are respectively called red and black fish. Each pair now begins to make a furrow in the gravel, working with their snout against the stream; when this is finisherl, the female deposits a number of her egrgs in it, and covers them up. The pair then proceed to work out other furrows, and in about ten or twelve days the whole of the eggs are deposited. Supposing the ergs to be deposited early in November, they are hatched in March, or early in 
April, and the young fry exhibit a rapid growth.

After sparning, the salmon begin their descent to the estuary, and so enter the sea, to commence their re-ascent in autumm. The salmon fishery, as by enactments ordained, is open from the 1st of February to the 14th of September, in the Scottish rivers. Various modes are employed in capturing this fish; many are taken by the skilful fly-fisher, whose address is tested to the uttermost by such an antagonist as even a moderately sized salmon. MIr. Stoddart relates that on one occasion in the Tweed, a farourite river for the salmon fisher, sir Humphrey Dary struck an immense fish, weighing above forty-two pounds, immediately above Iairbridge, and landed him after a serere struggle. MIr. Lascelles records the capture of a fish, weighing fifty-four pounds and a half, by the angling-rod, observing, that it was the Iargest salmon taken with a fly he ever knew in Scotland. It is not, however, we weed scarcely say, by the angling-rod of the fly-fisher that the markets are supplied during the spring and summer. Nets of different kints are the most effective, and of these we may first notice the stake-net. In the spring, as we have saicl, the salmon remains in the broad 
estuary of rivers, ascending with the floodticle, and returning with the ebb. For many a mile on each side, extending between high and low water-mark, are fixed nets of a peculiar construction, supported on firm stakes, and deepening, to meet the increasing depth of the water, from the edge of the shore to the lowwater line. These stake-nets are generally placed in opposition to the tide, so as to capture the fish brought up the estuary. Their form is better delineated than described. We must

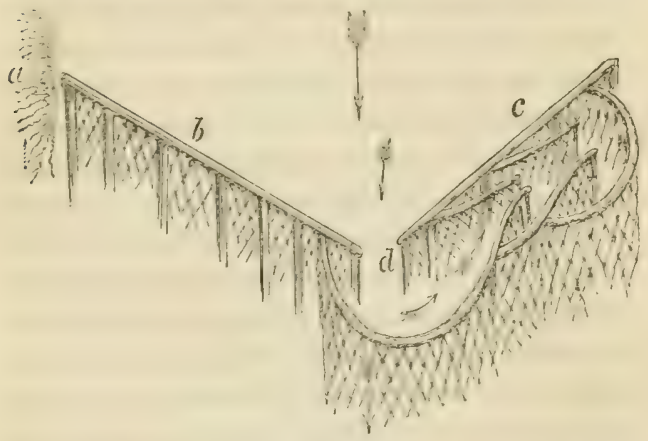

imagine the tide coming in, and the upper part of the stake-net only visible above the water. Suppose from the hank, a, two perpendicular converging walls of net, $b$ and $c$, extending to low-water mark, form a sort of embouchure 
opposite the tide coming in, as indicated by the arrows; a narrow passage, or open gateway, $d$, leads into netted chambers, into which the fish, conducted by the position of the nets constituting the embouchure, are gradually forced, and from which they cannot escape. These nets catch the fish asconding with the tide, but other stake-nets in the opposite direction, against the ebb of the tide, intercept many fish descending with it. In the centre of the stream, men in boats are engaged with sweep-nets, by which they surround several fish at a time. During the summer, when the fish rove aiong the sea-shore, seeking the mouths of the rivers previously to commencing their autumnal ascents, in order to the capture a long net is projected from the shore into the sea, making a considerable bend or half-moon; from its remote or seaward extremity long cords extend obliquely to another part of the shore, and by these cords the net is drawn in, from time to time, inclosing in a more and more circular swcep the fish within its flexure. This mode can only be used in particular localities, where the shore is fivourable. In some rivers, dams are partially thrown across the stream, with openings leading into inclosed chambers or crevices; into these crevices the ascending fish enter, but are 
prevented by a grating of peculiar contrivance from making their escape. On the flats in Solway Frith, a large funnel-shaped net, with a wide mouth, is used. Different localities and accidental varieties in the characters of the shore, or any given part of a salmon river, require different methods, and hence the various kinds of traps, decoys, and nets that are in vogue, each in its appropriate place. In the Severn, for example, the fishermen proceed in coracles (or wicker boats, covered with canvass, tarred and painted,) to the fishery, using several kinds of drag-nets.

In the salmon rivers of Scotland, a small fish, having transverse dark marks across the back to the lateral line, is known under the name of the parr. By many observers it has been, and still is asserted, that the parr is only the young or smolt of the salmon at a certain stage of growth; some, on the other hand, regard it as a variety of the young of the common trout. It is the Salmo salmulus of Willoughby, and we believe, with Mr. Yarrell and sir W. Jardine, that it is a distinct species from either, one of the smallest of the family; and it is remarkable, that in those unprotected rivers, from which poaching has driven the salmon, it abounds in profusion, as well as in some streams which the salmon 
never visit; while in others, frequented both by the salmon and the sea-trout, it is not to be found. Nor is it the young of the common trout, from which it differs in various anatomical peculiarities. The young of the salmon, the bull-trout, the common trout and others, have dark transverse marks, which become lost sooner or later, depending on the ultimate size of the species. "Thus," says Mr. Yarrell, "they are soonest lost on the salmon, and on the bulltrout, and are borne the longest on the common trout and parr; indeed, I have never seen the parr at any age or size without some trace of the remains of these markings. It is this similarity in marking and appearance of the fry which has caused the difficulty in distinguishing between the various species when so young, and experimenters, believing they had marked young parr only, have been surprised to find some of their marked fish return as grilse, young bull-trout, or whitling, salmon-trout, river-trout, and true parr." Mr. Yarrell alludes to the young of other animals being marked, and ultimately losing markings, which are permanent in other species of the fumily ; thus, the young lion and the puma are marked like the young of the tiger, and the young of all deer. are spotted, though the greater number of the 
species when adult are plain. Formerly, when the water of the Thames was purer than at present, the parr or samlet was common between Staines and Chertsey, and was known by the name of the skegger." It is now rarely to be found, and a Thames salmon is out of the question.

Perfectly distinct from the salmon, and next in estimation, is the salmon-trout, (Salmo trutta.) It is migratory, like the salmon, but never attains to so large a size, averaging only a few pounds' weight, though one of seventeen pounds was once seen by Mr. Yarrell. It is now a permanent resident in a fresh water lake of Lismore, one of the Hebrides. It occurs in the Sandwich river, and occasionally in the Thames and Medway; it is the Forbridge, or Fordwich trout, thus referred to by Walton : "There is also in Kent, near to Canterbury, a trout there called a Fordidge trout, a trout that bears the name of the town where it is usually caught, that is accounted the rarest of fish."

Vast quantities of salmon trout are sent to the London market from Scotland, and many persons regard them as young salmon.

* Walton notices this little fish as common in the Thames abort Wizdsor. 
In some of the rivers of Scotland and England the bull-trout, or whitling, (Salmo eriox, ) is very common; it is as large or nearly so as the salmon, but its flesh, which when in season is of a pale orange colour, is not held in much estimation. Very few are ever sent to the London market. The local names of Norway trout, round-tail, sea trout, Warkworth trout, and coquet trout, are referrible to this fish.

The clear streams, the swift gravelly rivers, and the pure fresh water lakes of the British islands, all abound more or less with that delicate fish, the common trout, (Salmo fario,) respecting which anglers, from Izaak Walton downwards, have written so much, each giving preference to the fish of different rivers according to his funcy. Walton praises the "swift, shallow, clear, pleasant brooks" of Hampshire, with their "store of trouts." Cotton exalts the Dove, the IVye, the Derwent, and the Lathkin of Derbyshire. But perhaps finer trout are nowhere to be found than those in the Thames, about the weirs of Hampton Court and Chertsey, about Pangbourne, above Reading, and in the deep pools above Oxford. We have ourselves seen Thames trout between eleven and twelve pounds' weight; but some of fourteen and fifteen pounds' weight are occasionally taken, not, 
however, without such a struggle as to bring all the skill of the angler into full play.

In 1832, a trout, thirty-one inches in length, twonty-one inches in girth, and seventeen pounds' weight, was taken near Great Driffield, (Yorkshire,) and one in the same year, January 11th, in a small branch of the Avon, at Salisbury, weighing twenty-five pounds. The trout feeds on flies, and the larvæ of insects, on small fishes, etc., and is extremely wary, active, and vigorous, leaping out of the water at its insect prey, and pursuing its finny victims with wonderful velocity. It bites eagerly at the May-fly, which proves a most destructive bait; and various artificial flies, suited to different streams or rivers, are also used by the angler; the larger trout are generally taken by spiming or trolling with a small bleak or gudgeon. The trout is in perfection in May, June, and July, (October being the breeding season,) and its colours are very beatutiful during those months, the numerous reddish brown spots and bright red spots, on its back and the upper part of the sides, being clear and distinct; the lower parts of the sides being golden yellow, and the under parts silvery white. There is, however, great variety in the colour of the trouts of different rivers, some being darker, some lighter in their 
tints, and in the black rivers running over beds of shale, in the moorlands, as the upper part of the Wye, near Buxton, in Derbyshire, we hare seen the small trout of an almost inky hue; while in the same river, along the Bakewell road, on its way to join the Derwent, where the water is beautifully clear, the trout are of a pale golden colour and beautifully spotted. They are, however, seldom of very large size.

The tront would appear to be a long-lived fish; at Dumbarton Castle a trout died, in 1809, which bad been liept, as asserted, in the well for twenty-eight years; and the Trestmoreland Advertiser, in August, 1826, contained, as Mr. Yarrell states, a paragraph respecting a trout which had lived for fifty-three years in a well in the orchard of Mr. W. Mossop, of Board-hall, near Broughton-in-Furness. The flesh of the trout is rery delicious, and when in full season of a pure salmon-pink colour.

In Lnugh Neagh, a variety called the gillaroo trout exists; we have seen specimens of it; it differs in having the lining cuticle of the stomach thickened, or rather indurated, and in the number of fin-rays, thus :-

Gillaroo trout, D 12. p 14. v 9. A 11. c 19. Common trout, D 14. P 14, and as above. Trout from various lakes, with the upper 
jaw unnaturally abbreviated, are not uncommon; they exist in some lakes in Wales, and Loch-dow, Inverness-shire. They are merely instances of hereditary malformation.

In some of the lakes of Scotland, Cumberland, and Ireland, as Loch-awe, Ullswater, Lough Neagh, etc., a large species of trout, called the great grey trout, or the great lake trout, has been long known to exist. This species is extremely savage and voracious, feeding principally upon other fishes, among which the small common trout must be enumerated. We have had an opportunity of seeing specimens nearly a yard in length. Young fish of this species will rise at an angler's fly, but the larger ones can only be taken by trolling in a boat, the bait a small trout, and the tackle extremely strong. The flesh is indifferent, and of an orange yellow.

The lakes of Cumberland, Westmoreland, and Lancashire, some of the Scotch and Irish lakes, and the lake of Geneva, afford a delicately fiavoured fish, known as the char, charr, or alpine charr, (Salmo umbla;) the potted flesh of which, though often mixed with that of trout, is sent to London.

The charr averages from nine to fourteen inches in length; it is very shy, and does not 
rise well at the $\mathrm{fly}$, but is, nevertheless, sometimes taken by the trout-fisher; it will bite at the minnow more readily, and is often taken in deep water by drawing the bait sunk by means of a lead, two or three feet above the minnow, after a boat. The lake is to the charr what the sea is to the salmon; on the approach of the breeding season, they ascend the rivers or feeders of the lakes, selecting those in preference which have a hard, stony, or rocky bed. Hence the charr of Windermere, contrary to the trout, choose the Brathy in preference to the sandy-ledded Rothay; and in November and December the shoals make their ascent. The flesh of the charr when in season (namely, June and July) is beautifully flaky, and of a fine orange tint. From unknown causes, charr, even at the same season of the year, differ considerably in colour, hence the terms of gilt charr, red charr, silver charr, and case charr, applied in reference to this diversity. Dorsal fin, thirteen rays.

Distinct from the northern charr, is a species found in some of the lakes of Wales, and more particularly in the deep Llyn Cawellyn, on the side of Snowdon. It is the Welsh charr of $\mathrm{Mr}$. Yarrell, and the torgoch or red-belly of the Welsh, (Salmo salvelinus, Donoran.) 
This fish is comparatively deeper and stouter than the northern charr, with considerably larger fins, a large eye, and much wider gape. The flesh of this species is excellent, but is little known beyond the territory adjacent to the waters, which the fish has long tenanted. It is abundant in the lake Cos-y-gedawl, in Merionethshire.

In many of the clear rock or gravel-bedded streams of our island, a beautiful fish, called the grayling, or umber, (Thymallus vulgaris,) is very abundant; it is found in the Trent and Dore, and in the Wye, at Bakewell; the streams of Hampshire and Wiltshire produce it ; several rivers in Wales, Yorkshire, Lancashire, and Cumberland, are also noted for it. This elegant fish is no less beautiful than excellent for the table, and it comes into season in October and November, when trout is out of condition, its breeding time being April or May.

The grayling feeds on insects, small mollusks, etc., and rises like the trout, at the angler's bait, but less dashingly. It has always appeared to us a less vigorous and active fish than the trout, and by no means so capable of stemming the force of a rapid current, nor have we ever observed it leap out of the water, as we have so often seen 
the trout, on a calm morning in May, while the May-flies, "thick as autumnal leares in Valombrosa," were dancing over the stream.

On the continent, if Domovan and Bloch are correct, (but certainly not in England,) the grayling passes the winter in the seas or the estuary, ascending the river in the spring, and remaining there till autumn. We say "not in England," because we have known the grayling in the Wye and Derwent, not only through the summer but the winter also, the fishing season for it being during the winter months; and though not a professed "brother of the angle," we have ourselves taken it at that time of the year. We believe, however, that the writers referred to are in some degree correct, for sir $\mathrm{H}$. Davy ascertained that the grayling of England will bear brackish water without inconvenience.

When freshly taken from the water, this fish has a peculiar aromatic and agreeable odour, which should not be allowed to fade before it is dressed for the table. Walton thus writes respecting this fish: "Gesner says, that in his country, which is Switzerland, he is accounted the choicest of all fish," etc. "Some think he feeds on water-thyme, and smells of it at his first taking out of the water;" from this thymelike odour originates the generic term, thymallus. 
We have never seen grayling more than from nine to fourteen or fifteen inches in length, but examples are on record of fish weighing from four to five pounds; such specimens are, however, very rare.

The grayling is remarkable for the height of the first dorsal-fin, which is crossed with square dusky spots; the head and back are dusky brown, the sides of the body of a light yellowish brown, with golden, green, and blue reflexions, and about fifteen dusky longitudinal lines, with scattered black spots; the head is small, and the scales rather large.

In some of the lakes of Ireland, a fish of this family, termed the pollan, exists abundantly, and in the lakes of Wales and Cumberland a fish called the gryriad, or schelly, is found. $\Lambda$ fish known as the vendace tenants the lakes of Dumfriesshire.

We must not here omit the smelt, termed in some counties the sparling, (Osmerus eperla. nims,) so noted for its cucumber odour, and so well-known in the markets of Lonclon.

This delicate little fish is not found along the line of our southern shores from Dover to Land's End, but is common on several parts both of our west and eastern shores, migrating in August up the rivers, where it remains till 
May, its breeding time being in March. Formerly the smelt advanced up the Thames as far as IIammersmith, but of late years various causes have combined to deter the advance of the shoals which enter the Nore and the Medway, where the fishing is carried on from the 28th of August to Good Friday. Large quantities of smelts are taken on the Lincolnshire coast; in the Tees and Humber, in the Frith of Forth, in the Solway Frith, and also in the Dee and Mersey.

The smelt, as we have said, breeds in the fresh water, and resides there throughout the greater portion of the year; and as experiments have prover, it will not only live but thrive in fresh water pounds, or sheets of water, into which it has been introduced, and which have no communication with the sea, so that it may be easily converted into a lake fish, without any deterioration of quality. Considering the demand in the markets for this fish, it is somewhat surprising that so little attention has been paid to this circumstance.

The ordinary length of the smelt does not exceed six or seven inches; we have seen some measuring nine, and even ten; we believe that, occasionally, still larger specimens occur. The smelt is too well-known to need description, and 
we have already pointed out its distinguishing differences from the atherine, or sand-smelt, of our southern coast.

A little silvery fish, called the argentine, (Scopelus Humbolutii,) is sometimes, but very rarely, found on various parts of our coast. Cuvier says it is taken in the Mediterrmean, mingled with anchovies.

Here we close our sketch of the salmon family, easily distinguished by the adipose or fatty texture of the second dorsal fin, which is destitute of rays.

The next family to which we shall attend is that of the herrings, pilchards, etc., termed Clupeide. Of these, the herring may be first noticed. Notwithstanding Pennant's account of the migration of these fishes in vast shoals from the high northern latitudes, dividing and subdividing, as islands and capes of the main land sever their ranks-a statement copied into most of the popular accounts of the day, without a single inquiry -it is now ascertained that such a procedure is not the fact. In short, Pennant's details are erroneous. The herring is not a fish of the high northern latitudes; voyagers do not find it in the arctic waters-at least it is rare. Crantz, in his Ilistory of Greenland, says: "The proper herring does not come into 
this latitude;" but he adds, "some few are taken in the south, probably wanderers." On the other hand, he notices a distinct but far smaller species as common. His words are: "The Greenlanders have their most common food from their augmarset, or small herring, a kind of lodden, called by the Newfoundland men capelin, * near half a foot long; their back is dark green, and their belly silver white. Like herrings, they swim into the bays in such quantities, to lodge their spawn on the rocks, that the sea looks black, and is ruftled or curled. They make their first appearance in March or April, and the common gull is their betrayer. They spawn in May and June, aud this is the Greenlander's' harrest, when they lade out whole boats' full in a few hours, with a hoop-sieve, knit with sinews. They dry them on the open rocks in the air, and then pack them up, and lay them by for winter, as their daily bread." The fact is, that the herring is a deep water fish, adrancing towards our shores for the purpose of breeding; and thence retiring to the deep again.

The herring spamns in October, or the early

* Dried capelins are sold in the Iondon markets; they have a peculiar flavour, sometling like th: of hurned leather, that is, letting the sense of smell stand fur that of taste. Some persons like them. 
part of November; and about three months previously to this they assemble in vast shoals, and gradually approach our coast, sometimes frequenting for years certain localities, which, from some cause not well understood, they do not again visit, or only in trifling numbers. Hence it happens, that the various herring stations around our coast experience great fluctuations, not only as to quantity, but also as to the time of the arrival of the shoals. *

* The subjoined notice appeared in one of the public papers on June 18th, 1846:-

"Henking Fisming.-It gives us great pleasure to state, that the herring fishing in Lochfine has been very successful this week, and the fish of the best quality. The market, on Thursiay, was more than abundantly supplied from Tarbet, Lochgilphead, and lnverary, the latter station furnishing by far the best fish. The abundant take allowed a great many boxes, alout sixty in number, imported here by Mr. WV. Gallocher, to be sent to Glasgow, Paisley, Dumbarton, and Liverpool. The herrings were selling here at fire for sixpence on Thurstay. The process of curing was also rigorously carricel on by him at the market, so that our denizens will have it in their power to partake of new cured herrings. On Thnrsiay aftemoon, the Canuhelton steamer passed with upwarls of 100 barreis of cured hemings for the cilasgow market. This is a gond stuply'y, although the fish are small in size, and not equal in quality to the Lochtine herrings." - Grecnocts $\therefore$ liveriser.

We ald the following, datel Felumary 12th, $18 \mathrm{ib}:-$

"TAKe of Merings. - We are hay) to state, that the sreatest take of lerrings within the nemory of the oidest iahnbilant of this island has occurred in our bay (Dugort) durin: the last three weeks. We may safely state, that uywaids of 300,000 herrings were caur:ht, and sold at fiar prices,

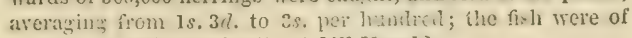
more than orclinary sizc." - Achill IIerald 
On the appearance of the herrings off our coast, the fishery commences, and the nets of au active, busy class of men are in full requisition. It is, however, only at night that the great work goes on. The nets used are termed drift-nets, suspended at different depths in the water, according to the distance below the surface of the water at which the shoals are pursuing their course. During this season countless thousands are taken by man. Porpoises and large fishes prey unceasingly upon them, and sea-birds join in the feast; among these latter, gannets and cormorants are conspicuous. Buchanan calculates, that the gannets of St. Kilda alone (to say nothing of those of the Bass Rock and other places) destroy amnually one hundred and fire millions of herrings; Jet, neither the destructive operations of man, nor of sea-birds, nor of large fishes, all cumbined, perceptibly diminish their numbers. Ilow wise are the provisions of the Divine Creator, who careth for the wants of all his creatures!

Young herrings in shoals are abundant around our coast during the whole of the summer, tenanting the shallows, and roving about from place to place as instinct prompts them. They continue during the autumn and 
winter in the estuary of the Thames, and the sprat-fishers often take considerable numbers. In some parts of the coast these young fishes are termed herring-sile, and yawlings.

Besides the common herring, a distinct species visits our coast in autumn. It is termed Leach's herring, (Clupee Leachii, Yarrell,) and was first discriminated by Mr. Yarrell, who gave a detailed account of it in the Zoological Journal, vol. v. This species is caught often in considerable numbers in the estuary of the 'Thames during the winter; it is smaller than the common herring, not exceeding seven inches and a half in length, and superior in flavour; in proportion to its length, it is much deeper than the common herring, and differs, moreover, in the number of the fin-rays and of the vertebræ. It is taken in Cardigan bay, and various bays and lochs in Scotland. The breeding season of this species comnences in the middle of February.

On our southern coast, and especially that of Devonshire and Cornwall, the pilchard (Clupea pilchardus) is taken at certain seasons of the year in great abundance. 'This fish does not travel so far northwards as the herring, but contents itself within temperate latitudes, never being found in the northern ocean. It is com- 
mon on the coasts of France and Spain, but seldom appears there in such countless shoals as it does along those of Cornwail and Devonshire, where, as we have said, an extensive fishery is carried on. This fish seldom departs far from the coast; but in July it assembles in astonishing multitudes, when the autumn fishery commences, the sean and the rlrift-net being chiefly used.

Pilchards, often in large shoals, visit different parts of the coast of Ireland, and there is a regularly conducted fishery in Bantry Bay.

The following extract will serve to show the enormous quantity of these fishes which are sometimes taken :- "A fisherman, now alive, was present once at the taking of two thousand two hundred hogshearls of pilchards in one sean. An instance has heen known where ten thousand hogsheads have been taken on shore in one port in a single day; thus providing the enormous multitude of twenty-fire millions of living creatures, clrawn at once from the ocean for human sustenance." The number of fish in each hogshead is two thousand five hundred. "The outfit of a sean amounts to about $£ 800$; a string of drift-nets will cost about $€ 6$; the net and the boat from $£ 100$ to $£ 150$. In 1527, the coit of seans and hoats used in this 
fishery, principally in Cornwall, was $£ 209,840$, and of drift-boats and nets, $£ 61,400$. The nets are supposed to last about six years, and ought of course to produce their own value within that time, together with an adequate profit; but it is the complaint of the fishermen that this is not the case. The profit of the men depends on the share of the fish, which is divided into eight parts, of which the boat has one-eighth Iart, the nets three, and the men four. A boy that accompanies them is rewarded with the fish that may fall into the sea as the nets are drawn, to secure which he is furnished with a bag-net at the end of a rod, termed a keep-net."

The pilchard much resembles the herring, but is shorter and thicker. It is principally to different ports along the northern shore of the Mediterranean that the cured pilchards are exported.

Along various parts of our coast, that wellknown fish, the sprat, (Clupea sprattus,) is taiken during the winter, the fishing season commencing in November. This fish abounds along the shores of Norfolk, Suffolk, Essex, and Kient; it is comparatively rare along the Cornish coast, but it is very abundant along the southern shores of Devon. Its movements, however, are 
very capricious. 'Tons' weight of sprats are often taken, and in some districts are used for manuring the land, and immense quantities are sent fiesh to the London market, as they are in request with all classes. At Lowestoft and Yarmouth, thousands are cured and dried in the same manner as herrings. 'They are sold by the dozen, or in bundles of one thousand each, tied up with twisted straw, and sometimes in small barrels.

Sprats are often caught by means of driftnets, made of fine twine, with small meshes, but more frequently by means of stow-boat nets, like large bag-nets, the mouth of which, twenty-two feet wide and thirty-six feet high, is kept square by means of beams and a heavy anchor, at a proper distance under the boat. The net is so moored that the tide carries everything into it. On raising the net, the beams which keep the mouth open are brought togrether in such a manner as to close it, thus securing the shoal within.

Formerly, many naturalists were disposed to regard the sprat as the young of the herring or the pilchard, but their opinion is now proved to be erroneous. Besides many variations in the position of the fins, one characteristic of the rprat consists in the serration of the abdominal 
line, or edge, which is so distinct as to prove an index to the fisherman in the darkest night. Dr. Parnell informs us, that sprats are found in the Frith of Forth throughout the whole of the year; and that, like many small animals, they appear to be very susceptible of cold. "During the warm summer months, they are seen sporting about in large shoals, in every part of the Frith, occupying a considerable extent of water, and causing a ripple on the surface with their fins, while they become the principal food of many marine birds, which assail them in the water, or prey on them from above. As the cold weather advances, these little fish are no longer seen in the lower part of the estuary, but are found to ascend the Frith to a considerable distance, and to select that part of the river where the fresh and salt waters mingle together; for it is a well-known law in chemistry, that when two fluids of different densities come in contact, the temperature of the mixture is elevated for a time in proportion to the difference in density of the two fluids. Owing to mutual penetration and condensation, such a mixture is constantly taking place in rivers that run into the sea, and the temperature of the mixed water is accordingly elevated. In the year 1830 , the sprat was remarkably abundant 
all orer the liritish coast, but more particularly on the coasts of Kent and Essex, where they were taken in immense quantity, so that they were sold at sixpence a bushel as manure for the land."

The sprat, according to Dr. Parnell, breeds early in March; * it feeds on small crustaceous aninals. In Scotland it is called the garrie, or garvie-herring.

A silvery little fish, well-known as the whitebait, (Clrpea alla, Yarrell,) is a visitor to the Thames, remaining in the brackish water from the beginning of April to the end of September. Donovan and others regarded the whitebait as the young of the shad-an error now rectified. Is is not only in the Thames that whitehait is taken; it is found in the Hamble, which flows into the Southampton water, and according to Dr. Parnell, it inhabits the Frith of Forth in considerable numbers during the summer months, especially in the neighbourhood of Queensferry.

In the Thames, the whitebait advances with the flow of the tide as high as Woolwich or Blackwall, returning with the ebb to the wider portions of the river, where the water is permanently

* Mr. Yarrell has seen the sprat taken in June, then in roe. 
brackish, and not as at Woolwich only during high tide, after the influx has arrived at its maximum.

The whitebait fishing is by means of a fine bag-net, with a mouth of about three feet square; the boat is moored in the tide way, and the mouth of the net does not dip more than four feet below the surface.

'The delicacy of the whitebait needs no comment. Pennant states it to be delicious, and says that epicures of the lower order resort to the taverns adjacent to the places where it is taken for the purpose of enjoying it. Mr. Yarrell makes the following comment on Pennant's observations: "What might have been the particular grade of persons who were in the habit of visiting Greenwich to eat whitebait in the days when Pennant wrote, I am unable to state; but at present the fashion of enjoying the excellent course of fish, as served up either at Greenwich or Blackwall, is sanctioned by the highest authorities, from the court at St. James's Palace in the west, to the lord mayor and his court in the east, including the cabinet ministers, and the philosophers of the Royal Society."

It is to Mr. Yarrell that we owe the discrimiaation of the true specific distinctness of this fish. 
Tro species of shad, termed by Mr. Yarrull the twaite shad (Alosa finta) and the allice shad, ( $A$ losa communis,) enter our rirers at certain seasons of the year, but generally in May, the former being common in the 'Thames, the latter rare in that river', but abundant in the Severn, as is the twaite shad also. These fish inhabit the northern seas, and are doubtless "the large sort of herrings" mentioned by Crantz, as occasionally taken along the south of Greenland. (See also Anderson's Account of Iceland.)

The allice shad exceeds the twaite shad in size, and usually weighs about four pounds; the twaite seldom so much as two pounds, and is a fir inferior fish for the table. It differs from the lar'ger species in possessing teeth, and being marked with several dark spots in a line along its silvery sides.

We must not leave this group of fishes without noticing one which is regarded by the cook as very important. TTe allude to the anchory.

Though the anchory (Engraulis encrasicolus) is not very abundant in our seas, still it is not unfrequently taken, and may be fairly ranked among British fishes. During the winter, it is found in the Cornish sea, and has been taken on the Iramplive coast, in the 
Bristol Channel, and some other localities. In the Mediterranean it is rery common, and among the ancients it was in high esteem, a liquor termed gamm being prepared from it.

Large quantities of pickled anchovies are imported into England; each fish is deprived of its lead, gills, heart, and other viscera, before being pickled, otherwise the condiments would be intensely bitter - in fact, it was anciently believed to have its gall in the head.

We have no means of estimating the quantities of anchory imported into England; but the total must be immense, when we consider that anchovies picl:led, and anchovy sauce, are found so generally on dinner tables throughout our land, and that in every Italian warehouse and fish-shop an abundant store is ready for purchase. 


\section{CHAPTER V.}

FISHES WITI SOFT FIN-RAYS, AND THE VENTRAL FINS DIRECTLY BENEATH THE PECTOIAL.

WE may now turn to the second division of the malacopterygious order of osseous fishes, termed "Malacopterygii sub-brachiales" in which the ventral fins are placed immediately below the pectoral, the internal bones sustaining the latter, giving attachment to those supporting the former as a fixed base.

The family of the cod-fish, (Gadidce, ) which first presents itself, includes many species; among these we may first notice the common cod-fish (Morrlua vulgaris.)

The cod-fish, of which we have mentioned two varieties, namely, the long-nosed, dark, "Doggerbank cod," and the blunt-nosed, yellowish, "Scotch cod," is widely spread in the seas of Europe and North America. It does not, however, exist in the Mediterranean. If 
we consider the thousands to whom the capture and curing of this fish afford employment, and the extent of its sale, both fresh and salted, within the British islands alone, we camnot help ranking it amongst the most important of the productions of the sea, which an all-wise Creator has appointed for the benefit of the human race.

We shall not attempt to eumerate various stations along the coasts of Scotland, England, and Ireland, where the cod-fishery is carried on. Formerly the London market was supplied from Scotland and the Doggerbank, but within the last few years numbers have been procured from the coasts of Lincolnshire, Norfolk, Suffolk, and even Essex.

The cod is a ravenous fish, inhabiting deep water, varying from twenty to forty-five fathoms, where sand-banks afford a favourable feeding-ground. In such situations there is an assemblage not only of cod, but of other white fish, the stronger making the weaker their prey. Besides fish, crabs and testaceous mollusks are the food of the cod, and numbers of these are often taken from its stomach. As the cod keeps to the ground at the bottom of a deep sea, nets are not employed in its fishery, but hooks and lines, variously arrauged on different 
parts of the coast. One mode is by bulters. Tive must suppose a long rope, to which, at given intervals, short lines of fire or six feet long are attached, at a distance from each other of more than twice their length, to prevent the entanglement of the hooks; each of there short lines or snoods is armed with a hook, and above, the threads of the line are loosely arranged in parallel order, to prevent the teeth of the fish from snapping off the hook and escaping. In slack streams, this long array of fines and hooks is deposited in the water, and secured at full stretch with buoys, buoy-ropes, and grapples. The main rope is shot across the tidal influx, by which means the snoods and their hooks are carried out from the bulter line, and thus disposed in due order. Various small fish, and whelks, limpets, etc., are used for baits. The fishermen now wait the flow and ebb of the tide; they then examine their lines, and disengage the fish held captives. Sometimes a little cork is fixed about six inches from each hook, to raise the bait a little above the mud or sea-weed, thus presenting it more conspicuously as a tempting morsel to the fish.

In other instances, various sorts of hand-lines are used, each armed with two hooks; one 
man manages two of such lines, and the number of fish taken by the fishermen of a single ressel is often very great. Mr. Yarrell says, that he was told by the master of fishing vessels trading for the London market, that eight men, fishing under his orders, off the Doggerbank, in twenty-five fathoms of water, have taken eighty score of cod in one day.

The cod, after their capture, are transferred to well-boats, which come up the river as high as Gravesend, with the fish alive, the water being so far sufliciently brackish. From this depût they are sent, by speedy conveyance, to Billingsgate. The salted sounds, or air-bladders of the cod, are sold in the London market, and salted cod is well-known.

Cod-fish is in perfection from the end of October to Christmas; the breeding season is in February, and nine millions of eggs have been found in the roe of a single female. During the summer and autumn, young cod-fish abound around our shores, and adrance up the estuary of the Thames; they acquire a length of twelve or fifteen inches before winter ; numbers are taken by means of lines.

Large cod-fish are not uncommon; Pennant records one of the weight of serenty-eight pounds, caught at Scarborough; and Mr. Yarrell, one 
of sixty pounds, caught in the Bristol Channel. Such overgrown fish, however, are very indifferent. In some of the salt water ponds of Scotland cod-fish are lept, as in a sort of preserve; they are properly supplied with food, and kept in good condition, but we believe they do not breed.

The coasts of the British islands abound with vast shoals of the haddock, which wander about in quest of food, but they never make their way either into the Baltic or the Mediterranean. The haddock (1Lor hua aglejimus) never equals the cod-fish in size, being seldom more than two or three pounds in weight, though instances of this fish weighing ten and even sixteen pounds are on record. The breeding season is February and March. Haddocks are caught by trawl-nets, and also by hand-lines, by which means great numbers are taken for the different markets, those of London being largely supplied by the Yarmouth fishermen. The haddock is too well-known to need description; it is remarlable for the black mark on each side of the back.

A fish, called the pont, or whiting pont, the smeltie, the bib, the $\mathrm{kleg}$, and blinds, in different counties, (Morrhua lusca, is common in most parts along our coast, being often in abundance, 
especially about the mouth of the Thames. It ranges as far as Greenland, and is found on the coasts of Holland and France.

This fish, the flesh of which is well-flavoured has the power of inflating the membrane covering the eyes and the adjacent parts of the head, which produces a singular appearance. Like the whiting, it has a dark mark at the base of the pectoral fins. The trawl-net, and hooks and lines, are employed in its capture, the use of them depending on the nature of the fishing ground. It measures twelve or fourteen inches in length.

Another small fish, called the poor, or power cod, (Morrhua minuta) is found on the coast of Cornwall and Devonshire, and perhaps of other parts of our island; but, from its size, (being only about five inches long, or, perhaps, sometimes seven or eight,) it is not sought after by fishermen, whom a richer prize alone can remunerate. It is said to visit the Baltic in shoals, followed by the cod and other fishes, which make it their prey. Hence its appearance rejoices the Baltic fisherman.

Common upon our coasts, and those of Holland and France, and upon the various banks of our seas, the whiting (Merlangus vulgaris) occurs in abundance. This fish is much es- 
tcemed for the whiteness and delicacy of its flesh, and as it is taken nearly all the year round, (though it is in the highest perfection during winter,) there is a constant supply in the market.

Large individuals of this species are sometimes to be met with; we have heard, from undoubted authority, of one which weighed seren pounds, but few are seen in the shops of the fishmongers much exceeding a pound and a half in weight. This fish is taken by lines, and, being very roracious, it eagerly seizes the bait. It fieds upon fishes, small crabs, mollusks, ctc. The whiting is too well-linown to need description.

In the high northern seas, a species of this family, termed the coal-fish, or sillock, (M/Crlangus cartonarius, is extremely abundant. It visits the shores of the British islands, and especially those of Scotland and the Scottish isles, where it is taken in considerable numbers, and is eaten, both in its fresh state, and also when salted and dried, but its flesh is coarse and dry.

Young coal-fish malse their appearance early in the summer, and are taken by the hook and line, as are also the adult fish, which are extremely roracious. The lattur are $n$ the best 
state for the table in winter; they associate in large shoals, which rove about in quest of prey, and are readily attracted by the baits of the fisherman. The coal-fish often attains the weight of twenty or thirty pounds, but it is more esteemed when of a smaller size. The general colour of this fish above, as far as the silvery white lateral lines, is dusky black; the sides below the lateral line are greyish white, with golden reflexions. Both the adult and the young have numerous local names.

There is another species, termed the pollack, or Iythe, (Merlangus pollaclius,) common in our seas, and caught on varions parts of our coasts; it is much superior to the coal-fish in the delicacy of its flesh, the young being almost equal to whiting. The pollack is extremely active and voracious, seizing the baited hook with great avidity, and is consequently captured with little difficulty. The general colour of this species is olive brown on the upper parts; the sides are silvery, spotted with yellow; the lateral line, which makes a bold curve over the pectoral fin, is dusky.

The hake (Morlucius mulgaris) is another fish of the present family, found in the northern seas, and common along the coast of our island, and of the adjacent continent. It is taken in 
the Mediterranean, and its name, in the Prorençal language, is merlan. This fish is not very often to be seen in the London markets, although Portsmouth and Plymouth receive an abundant supply from the fishing-boats on the Deronshire coast. It is usually captured in nets, but lines are also used. Its llesh is coarse; it is, however, generally salted and dried for exportation to the continent. In this state, in common with the cod, it is called stock-fish. In the bay of Galway, and on the Nymph-bank, off the coast of Waterford, the hake is extremely abundant; and in the latter situation six men, Mr. Yarrell says, have taken, with lines, one thousand in a single night. The hake equals or exceeds the codfish in size; its scales are large; its general colour is dusky above, and paler on the lower parts.

On many parts of our coast, and that of Ireland, the ling (Lota molva) is a common fish, and caught in great numbers; the greater portion of the ling, which is captured, is salted and dried; the sound, or air-bladders, are cured separately, like those of the cod, and the liver yields a plentiful supply of oil, used by the poorer class in many districts, and in the Orkneys and western isles, for burning in 
lamps. This oil has been held in high esteem for the cure of chronic rheumatism; it must be taken in doses of half an ounce or an ounce, but its disgusting smell and taste, which are suffcient to excite nausea, prevent its frequent use. Cod-liver oil, or refined ling-liver oil, is at present in vogue as a medicine. What its specific properties may be we know not.

The ling is active and voracious, and is generally between three and four feet in length, sometimes more; but its form is slender. Its general colour is dusky grey, passing into white on the under parts.

In some of our rivers, as the Trent, the Cam, and those of Norfolk and Lincolnshire, Durham and Yorkshire, a fish known as the barbot, or eel-pout, (Lota vulgaris,) is to be met with, but in other rivers it is scarce or does not exist. It is a slender fish, weighing about two pounds on an average, and its flesh is excellent. This fish is fond of lurking in holes, or under large stones, where it watches for its prey. It is extremely tenacious of life, and will live long out of the water, like the eel, although its gillopening is large and its mouth wide. It has been introduced into the lake of Geneva, and might be placed with advantage in the meres and lakes of our island. The general colour is 
yellowish brown, marbled with a darker tint. Its surface is very slimy.

Passing orer sereral fish of little general interest, as the rocklings, the torsk, the forkbeards, ete., we may adrance to the fimily of flat fish, as they are commonly termed, (Pleuronectide, from their peculiar shape. Unlike the rays, which are flattened vertically, these fish are flattened laterally, that is, from side to side-the brown surface of a sole, for example, is only one side, and the white surface, on which it reposes, another side-and the head is as if it had been wrenched round and crushed flat in a distorted position. When the sole, on any sudden alarm, swims rapidly, it raises itself so as to show the white as well as the brown side, and shoots along. The flesh of many of these flat-fish is in high estecm. The habits of these fishes are in accordance with their form; they prefer tranquil bays, sandbanks, and spots where the water is muddy; as they lie flat on the white side, the position of their eyes gives them a great range of vision, and enables them to watch for their prey; while the brown or dark colour of their exposed side, blending with that of the bed around them, tends to their own concealment. These fish are mostly in shoals, and when they 
move along leisurely, a little elevated abore the bed on which they repose, they continue in their horizontal position; but when the shoal takes fright, all, at the same instant, show the white side, and dart forward with arrowlike velocity for a certain distarice, but soon arrain settle into their previous position. They are essentially ground-fish, and their food consists chiefly of small crustacea, marine insects, mollusks, etc., which they obtain in abundance. They are very tenacious of life; and some species may be seen leaping on the board of the fishmonger, in London and its precincts.

Of these flat fishes the plaice (Platissa vulyaris) is well-known; it is abundant on the English coast, wherever sand-banks and muddy beds invite its residence; it is taken both with the line and the trawl-net. In Scotland, the smaller sized plaice are termed fleuks; those taken on a particular station off the Sussex coast, remarkable for the brilliancy of their orange red spots, are termed diamond plaice, and the station is called the diamond ground. The plaice occasionally grows to the weight of ten, twelve, or fourteen pounds, but the average size varies from one to three or four pounds. Bushels are brought into the London market, and have sometimes been sold at a 
penny the dozen, each fish weighing three pounds on an average. This fish will live and thrive in fresh water, but so abundant is it, that its cultivation in such a wily in our country is useless. It is in the best condition at the end of May, and throughout the next month.

In all our bays and creeks, and in the mouths of our rivers, and far inland up the rivers, the flomder, fleuk, or flook, (Platessa flesus, is very common. It is found in the Thames as high as Teddington; it abounds in the Mole, and in the Aron, near Bath; we hare seen shoals of it in the Severn, near Berrdley. It will live in fresh water ponds, as well as in the sea, and out of the water is so tenacious of life, that it may he sent from one part of the country to another with little difficulty.

In the Thames, the fishermen take this fish by means of a tuck-net, which is so managed as to make a circular sweep, inclosing within it whatever fish may be swimming in the spot. The flounder is generally small, but specimens of two or three pounds' weight are occasionally to he met with. All are so well accuainted with this fish, that we need not describe it. 
A small flat fish, known as the dab, or salt water fleuk, (Plutessa limanda,) abounds on the sandy portions of our coast, and is sent in rast numbers to the London market. It is preferred to the flounder, and is in full condition during the early spring months. A distinct species, the town-dab, lemon-dab, or smooth dab, (Platessa microcephalus,) is also taken on many parts of our coast, but it is less common than the preceding species. Two other species of dab, the long rough dab and the pole, are occasionally found on our shores.

In the northern seas, a large flat fish, linown as the holibut, (Hippoglossus vulgaris,) is very common; it occurs on the shores of Scotland, and the north of Ireland. The size to which this fish grows is enormous; indivicluals have been captured nearly eight feet in length, and terrible must be the struggle in orercoming a fish of such power, and tenacity of life. Specimens of four and five feet long are often to be seen in the Loudon markets. The flesh of this fish is dry and coarse, and in England but little in request. It is one of the fishes, however, on which the Greenlanders subsist. Crantz, who describes the holibut, says : "The largest are a yard and a half or two yards long, about half so broad, and a full span thick; they weigh 
from one to two lundred pounds and more. They are saic to be so large in Norway, that one of them salted will fill upwards of a quarter cask." * The Greenlanders cut sirips of the Hesh of this fish, which they dry for use in the sun and air. Its flesh is prepared in a similar manner in Iceland, and also pickled with salt.

When the holibut finds itself hooked, its struggles are desperate, and it camnot be secured without considerable exertion.

That highly esteemed fish, the turbot, or Bannock fleuk, (Iihombus maximus,) is found on many parts of our coast, and there is a considerable fishery off the shores of Durham and Yorkshire, as well as along our southern counties, but the London market is chiefly supplied by the Dutch fishermen. The fishing season commences in March, and terminates in August. Both lines and trawl-nets are used. A writer of great authority says, the Dutch are supposed to have drawn not less than $£ 80,000$ a year for the supply of this fish to the London market alone, $\uparrow$ and " the Danes from $\mathfrak{£ 1 2 , 0 0 0}$

* They lare been taken reighing upwards of five hundred pounds.

$\dagger$ The English fishermen purchase at sea largely of the Dutch, nevertheless, the Dutch send boats latien with turbot up the Thames, each l.oat bringing atout one hundred and fitty fish, and paying a duty of 20 . 
to $£ 15,000$ a year for sauce to this luxury of the table, extracted from a million of lobsters, taken on the rocky shcres of Norway, though our own shores are in many parts plentifully supplied with this marine insect, equal in goodness to those of Norway." The finest turbot are taken on the Flemish banks, and the banks called Broad Forties. Excellent fish are also taken by the French fishermen, on the two large sand-banks, called the Varne and Ridge, stretching towards the French coast in the channel, not many miles from Dover. These they sell to the English out at sea, or send into Dover.

Turbot of huge size are occasionally taken, some of which have weighed from fifty to seventy pounds; and one was caught in 1832 , near Whitby, which weighed a hundred and ninety pounds. The average size is from three to ten pounds' weight.

The London markets are abundantly supplied with the brill, (Rhombus vulgaris,) the bonnet fleuk of the Scotch. This fish, which often attains to an enormous size, is abundant on our southern coast, and all the localities where the turbot occurs. It inhabits deep water and sandy bays. The brill is infericr to the turbot, its flesh being clestitute of that 
firmness which is so remarkable in the turbot, and for which it is so much prized.

Among these fishes, one of the most valuable is the sole, (Solea vulgaris,) which, if it were scarce, would be in high estimation. This fish is found around the shores of our island, and along those of the adjacent continent; it exists in the Baltic, and also in the Mediterranean. It usually tenants beds of sand, where it feeds on testaceous mollusks and similar prey. The sole is taken by the trawl-net, and there are numerous fishing stations along our coast, especially off Sussex and Devonshire, where vast numbers are captured, the supply appearing inexhaustible. The sule is in season all the year round, excepting during the latter part of February, when its flesh becomes fablyy. In a few weeks, however, it recovers and continues in excellent condition. Mr. Yarrell states, that in the course of one twelremonth, eighty-six thousand bushels of soles were received at Billingsgate market. Occasionally, this fish is to be seen of large size, weighing cigint or ten pounds - the pair; and there is an accomt of one lyy Mr. Yarrell, which was twenty-six inches long, deven inches and a half wide, and weighed nine pounds. It was in the 'Totness marliet, June 21, 182fi. Torbey i: nuterl fur it's fine 
soles, and extensive sole fishery. The sole will live and thrive in fresh water, and numbers reside and breed in the brackish water of the Arun, from its moutl to a distance up the stream of five miles. They are said to be of excellent quality. These Arun soles are reported to bury themselves in the sand, or mud, during the cold months; the season for trawling for them extending from May to Norember.

An allied species, the lemon sole, (Solec pegusa, first described by Mr. Yarrell, is occasionally talien off the Sussex coast; it is wider in proportion, and thicker than the common sole, and its coloux is a light brown, with a mixture of orange yellow.

Another rare species is the variegated sole, (Monochirus linguatulus, which has been captured on three or four occasions.

In the shops of the London fishmongers, a strange-looking, rounded fish may often be seen exposed to view. It is of a dark blue colour, varied with pale blue and purple, the lips and under surface being of a rich orange. This fish is called the lump-sucker, or sea-owl, (Cyclopterus lumpus,) and belongs to the family termed Cyclopterille. It possesses the power of allhering with great tenacity to rocks or stones, by meams of its pectoral and ventral 
fins, which are united together under the throat, and form a powerful sucker. 'The lump-sucker' is very widely spread in the northern seas. In Greenland it is eaten, and may be scen, according to Crantz, near the shore in April and May, but at other times is not to be found, as it "browses on the sea-grass in the deep."

On many parts of the coasts of England, Ireland, and Scotland, this fish is common, and especially in the Orkneys ; its flesh, and particularly that of the male, is regarcled as excellent. It is chiefly in April and May that the lump-sucker is taken, as it then approaches the shore for the purpose of breeding. What Crantz says about its browsing on sea-grass is not quite correct; it is a voracious fish, and preys upon smaller species and various marine insects. The lump-sucker is usually from twelve to eighteen inches long, and from six to eight deep; the lips are thick and fleshy, and the mouth wide; the whole surface of the head and body is covered with small bony tuhercles, among which are some rows of a large size and more prominent than the others. The eyes are large, and "make it look like a cat or an owl," whence one of its common appellations-sen-owl. 


\section{CHAPTER VI.}

FISHES WITHOUT VENTRAL FINS.

We shall now pass to the third order of osseous fishes, the Apodal, or footless, (Malacopterygii,) so called because they are destitute of ventral fins. 'The fishes of this order are elongated in form, and have a soft and slimy skin, which, although not without minute scales, may be called scaleless, as far as an ordinary observer is concerned. To give without further preface an idea of these fishes, we have ouly to state that the eels (Muranida) constitute the typical family.

Mr. Yarrell discriminates three distinct species of fresh water eels, if not four, and Cuvier distinguishes four, which have all been confounded together, although, when the species are compared, the distinctive characters are not difficult to be discorered. The species figured and described by Mr. Yarrell are the sharp-nosed eel, (Anguilla acutirostris,) the broad-nosed, or glut-cel, (A. latirostris,) 
and the snig-eel, (A. mediorostris, ) which last is of a yellow colour, and found in the Hampshire Aron, and in the Worcestershire Avon, where, in contradistinction to the silver eel, it is termed the yellow eel. In some counties, the term snig is applied to eels in general, and the term grig to young eels; there is, however, a small eel in the Thames, called grig by the fishermen, which is Curier's anguille plat-bec, regarded by him as a distinct species, and figured as such in Mrs. Bowdich's work on Fresh Water Fishes.

Our object, however, is not to enter upon minutiæ, yet we may observe, that of these species the broad-nosed, or glut eel, called by the Severn fishermen the frog-mouthed cel, is thicker in the body in proportion to its length than the others, and has a thicker, softer, and more sliny skin. The sharp-nosed eel is the species most usually seen in the London markets, and of which thousands are imported from Holland. Mr. Yarrell states, that there are two companies in Holland, having five capacious well-vessels each, in which large quantities of eels are preserved alive till wanted. "One or more of those vessels may be constantly seen lying off Billingsgate; the others go to IIclland for fresh supplies, each bringing 
a cargo of 15,000 to 20,000 pounds' weight of live eels, for which the Dutch merchant pays a duty of $£ 13$ per cargo for his permission to sell." Regulations of this nature are, of course, ever changing.

The eel inhabits rivers, meres, lakes, and ponds, but it is highly susceptible of cold, and during intense frosts, accompanied by a piercing east wind, thousands of eels, though buried in the mud, have been known to perish, and, crawling from their lurking holes in the agonies of death, have been washed down the stream to the tideway, and thrown upon the beach. Many instances of this kind are on record. In the high northern regions there are no eels-none exist in the great rivers of Siberia, in the Wolga, or in the lower Danube, which receives a vast influx of Alpine water, brought by the Inn, the Fraum, the Save, and Drave. Few or no eels exist in our mountain streams.

In lakes and ponds, or in rivers remote from the sea, the eel breeds, depositing its spawn about the end of April or beginning of May. But when the way is clear, eels migrate in vast numbers to the mixed and brackish water of the estuaries of rivers, during the autumn, where they deposit their spawn in warmer water during that season, or very early in the 
spring; and in the months of April and May following, myriads of young eels, about three inches in length, ascend the rivers, and fix their stations in different localities. Doubtless, many of the young remain permanently in the brackish water of the estuary, or eren in the salt water near the river's mouth. With respect to the adult eels, their return is not clearly ascertained; nor are we to suppose that all the adult eels in tidal rivers descend to the sea, for we know that they bury themselves in the mud to the depth of twelve or fifteen inches, and generally in such a spot as is covered by the water of a land-drain, when the tide is at its ebb. "In Somersetshire," says MIr. Yarrell, "the people know how to find the holes in the banks of rivers in which eels are laid up, by the hoar-frost not lying over them as it does elsewhere, and dig them out in heaps." * Nevertheless, that numbers of eels make an autumnal descent is unquestionable, and in tideway rivers, such as the Thames, permanent erections are constructed for their capture during their progress, trap-baskets of wickerwork, and other kinds of cages, being fixed in a proper manner, so as to intercept and

* In the upper Danuhe, about Ulm, eels abound, but do not migrate to the sea. 
secure them. Eels are also captured by nightlines and by eel-spears.

The eel lives long out of the water, and sometimes, during the warm nights of summer, when the dew is on the grass, voluntarily quits the pond or river, and proceeds with an undulatory motion on land, either in quest of worms and other prey, or in order to gain some other piece of water; and thus it often happens that meres or ponds become stocked with this fish, though none had been purposely introduced. One of the finest eels we ever saw we caught in a swampy spot, several hundred yards from the river Bollen, in Cheshire; and we have seen them in the dusk of evening, moving over the wet grass of fields bordering the Severn.

The eel is extremely voracious; it preys upon worms, insects, small fishes, and the eggs of fish; it also eats vegetable matters, and, as we have more than once seen, will swim about the surface of a pond, nibbling the floating leaves of the water-plants.

Unlike most fishes, the eel is of slow growth, and does not breed until two or three years have passed. The common sharp-nosed species attains, sometimes, to a very large size, and individuals have been occasionaily caught weighing upwards of twenty pouuds. 
Along the rocky parts of our shore, and about the mouths of rivers, where sand-banks stretch out into the sea, that large marine species, the conger-eel, (Conger vulgaris,) is often very abundant. It is caught in great numbers on the Cornish coast, by night-lines; and a single boat will often capture a ton, or even two tons' weight of this fish. Its flesh is principally used by the poorer classes; it is white and firm, but of indifferent flavour.

Congers hide in the holes of rocks beneath the sea, or in recesses corered with masses of sea-weed, and often, also, bury themselves in the sand or mud; they are extremely ferocious, and a diver, residing at Herne Bay, told us that, on one occasion, a large conger, which he had disturbed, swam sereral times around him, as if meditating an attack, but ultimately, to his relief, swam slowly away. It must be confessed, that a large conger, the strength of which is prodigious, and its powers of jaw terrible, must be no very despicable antagonist to contend with in its native element. Te have seein specimens of this fish eight and ten feet in length, and upwards of a hundred pounds in weight; such a fish, when dragged into a boat, would require both skill and courage to manage. 
The conger feeds on fishes and crabs and other crustacea; it breeds in the winter. Vast numbers of congers are taken by the French fishermen, who find a ready sale for this fish in the French markets.

We may here allude to that voracious fish, the muræna, so much esteemed by the epicures of ancient Rome. The murma (Murconc Hclena) can scarcely be classed among British fishes, though one specimen was caught by a fisherman of Polperro, in 1834. It is, however, common in the Mediterranean, and is noted for its voracity and the severity of its bite; though extremely beautiful in colouring, it is a hideous fish, with small eyes, tumid cheeks, and wrinkled skin; its teeth are in single rows, long and sharp; the body is rounded anteriorly, compressed and tapering towards the tail. The ground colour of the anterior parts is a fine Jellow, of the hinder parts a rich purple, the whole surface being marbled with somewhat annular markings, and sprinkled with innumerable spots of white, yellow, golden, browr, and purple.

On many parts of our shores a little slender eel-like fish, five or six inches in length, is very common. It is termed the sand-lance, (Ammodytes lancea, ) and is of a silvery brightness. It 
is captured in large quantities, but principally as a bait for the sea-lines, and bushels are sold to the French fishermen. Its under-jaw projects in a singular manner, and enables it to burrow into the sand, which it does on the ebbing of the tide, and emerges from its hole on the reflux. This fish is known as the riggle on the coast of Sussex. TVe have an allied species of larger size, but similar habits, called the sand-eel, (Ammodytes tobianus.) It is not very common.

The fifth order of osseous fishes, established by Cuvier, is termed Lophobranchii, in reference to the structure of the gills, which present the appearance of little rounded tufts, disposed in pairs along the branchial arches. They are covered by a large gill-flap attached all round, leaving only a small aperture for the passage of the water. These fishes, besides, have the whole body invested in a sort of cuirass, or tesselated armour, producing ridges and angularities. To this group belong five species of pipe-fishes found upon our coasts, remarkable for the length and slenderness of their body, and the tenacity and prolongation of the snout, into a sort of tube, with a small mouth at its extremity. The males of some of the species have an elongated pouch under the tail, closed by 
two folding membranes, and in which the eggs deposited by the female are hatched, although the time and mode in which they are transferred to this receptacle is unknown. Unlike most fish, the pouched pipe-fishes are strongly attached to their young, and when danger threatens, the pouch serves them as a place of retreat. Of these fishes, the great pipe-fish (Syngnathus acus) is one of the most common, and is often zept by the fishermen in a dried state to sell as a curiosity to sea-side visitors. It is from one to two feet in length, when fully grown, and is of a pale yellowish brown, with dark and broad bands at regular intervals. "This species," says Mr. Couch, " may be seen slowly moving about, in a singular manner, horizontally or perpendicularly, with the head downwards or upwards, and in every attitude of contortion in search of food, which seems chiefly to be water insects." Mr. Yarrell observes, that these fishes "are supposed to be able, by dilating their throat at pleasure, to draw their food up their cylindrical beak-like mouth, as water is drawn up the pipe of a syringe." The male of this species is furnished with a pouch.

Closely allied to the pipe-fishes are the Hippocampi, of which one speries the short- 
nosed hippocampus, is to be met with on different parts of our coast. This fish, often called the sea-horse, is of a singular form, the head resembling that of a hog or tapir, with a slender tulnilar snout, at the end of which is a small mouth. The neck is arched like that of a horse, and the protuberant abdomen may represent the chest; the tail is long, tapering, and prehensile; the dorsal fin is high; the mail-clad body and tail are traversed by longitudinal and transverse ridges, with angles of intersection.

Specimens of this fish have, it is said, been occasionally found curled up in oyster-shells, but of their general habits little is known; the following extract from Mr. Yarrell's work is therefore the more interesting: "At the time of writing, June 9, 1835, Mr. Lukis had two female specimens of IIippocampus brerirostris, then healthy and active, which had been living twelve days in a glass vessel; their actions equally novel and amusing. An appearance of search for a resting place induced me, says Mr. Lukis, to consult their wishes by placing seaweed and straws in the ressel; the desired effect was attained, and has afforded me much to reflect upon in their habits. They now exhibit many of their peculiarities, and few 
subjects of the deep have displayed in prison more sport or more intelligence.

"When swimming about they maintain a vertical position, but the tail is ready to grasp whatever it meets in the water, quickly entwines in any direction round the weeds, and when fixed the animal intently watches the surrounding objects, and darts at its prey with great dexterity.

"When both approach each other, they often twist their tails together, and struggle to separate or attach themselves to the weeds; this is done by the hinder part of their cheeks, or chin, which is also used for raising the body when a new spot is wanted for the tail to entwine afresh. The eyes move independently, as in the chameleon; this, with the brilliant irridescence about the head, and its blue bands, forcibly remind the observer of that animal."

The general colour of this fish is a pale brown, with changeable irridescence, and variable tints of blue. The males are furnished with a pouch. Total length, about five inches.

Cuvier terms his sixth order of osseous fishes, Plectognathi, from the imperfection of their jaws, the bones of which are firmly attached to the palate bones. The general structure of the skeleton is not so hard as in most other osseous 
fishes, and the gill-aperture is merely a small fissure, and the ribs are rudimentary. In some, as the globe-fishes, or diodons, tetraodons, etc., there are no true teeth, but the jaws are armed with a substance like ivory, resembling in form a parrot's beak, but of laminated structure. These successive layers succeed each other in proportion, as the more anterior are worn by the effect of crushing and grinding the seaweeds and crustaceous animals on which they feed.

In another family, containing the file-fishes, (Balistes,) and the box-fishes, (Ostracion,) the muzzle is produced and conical, with a small mouth, armed with distinct, but not numerous teeth in each jaw. Some of these fishes feed on corals and sea-iveed.

There are three instances on record of a species of globe-fish (Pennant's globe-fish) having been taken on the const of Cornwall, wanderers by accident from warmer latitudes. A species of file-fish has once been taken off the Sussex coast.

Two species of sun-fish are occasionally seen off our coasts, of which the short sun-fish (Orthagoriscus mola) is the most common. This fish is of a circular form, and though there is a caudal fin, united to the dorsal fin and the 
under fin, there is no tail. The javs are armed with an undivided cutting edge. This fish is very shining; it often grows to a great size, and has been taken weighing three hundred pounds, but such large specimens are rery rare. Generally these fishes are observed drifting along as if asleep on their side, but sometimes swimming in the ordinary manner; they keep much at the bottom of the water, and there feed on seaweeds. They often, however, ascend in calm sunny weather, and lie basking on the surface, carried along gently with the tidal current. 


\section{CHAPTER VII.}

\section{CARTILAGINOUS FISHES.}

Here we leave the osseous fishes, and pass to the section of cartilaginous fishes, (Chondropterygii,) in which the skeleton is never thoroughly ossified, but remains permanently as tough cartilage.

This class, or great section, contains two orders:- the first, containing such species as have the gills free; the second, such as have them fixed.

First order: GiLLS FreE.

In the fishmongers' shops of our metropolis, huge examples of the sturgeon, (Accipenser sturio,) a fish regarded as royal, is often to be seen. It is, however, only a royal fish when caught in the Thames, within the jurisdiction of the lord mayor, it being by ancient custom reserved for the royal tables. The sturgeon has a long, pointed, conical snout; the mouth opens underneath in the throat; the body is 
elongated, and defended by indurated plates and spines, arranged in longitudinal rows. This fish is often taken on various parts of our coast, and in the estuaries of rivers, where it is sometimes entangled in the salmon nets. Its struggles are very desperate, and it sometimes occasions much trouble. The flesh of this fish, which is sold in slices, is much esteemed by many; it is firm and white, like real, and generally prepared as a stew, with a rich gravy; it is also preserved by salting. The roe of the sturgeon on the continent is made into a condiment, called caviar, and the best isinglass is prepared from the membrane of the air-bladder. In the Caspian Sea, and in the northern districts of Europe, extensive sturgeon fisheries are established, the roe and air-bladder being the great desiderata. The Russian fisheries on the Caspian Sea are extremely valuable. In this great inland sea, besides the common sturgeon, two different species exist: one is the great sturgeon, Le Hausen, or Beluga, (Accipenser Haso,) which is from twelve to fifteen, and sometimes twenty feet long, and weighing upwards of two thousand pounds, with a roe of five or six hundred pounds. The other is a smaller species, usually from four to six feet long. It is the sevruga, or sevreja, of the 
Russians, the schorg of the Dutch, (Accipenser helops.)

The first fishery of the great sturgeon begins in April, at the various stations along the coast. The lines laid down are on the same principle as the bulters and snoods described as made use of in cod-fishing, but of course the tackle is of far greater strength. These lines are examined twice a day, and the fish which are caught are disengaged, and when a rope from shore is passed through their gills, they are put into the water, to be kept alive till the time for cutting them up arrives. A single vessel will sometimes capture fifty of these fish in twenty-four hours. The work of cutting up these fish is managed on planks, along the shore. The sounds are obtained by the isinglass makers; the roes are put into tubs, of which the preparers of cariar take the charge; the fish is then cleared of refuse, cut up, and put in layers into brine vats in underground cellars, for the sake of coolness; after this, the fish are taken out, again sprinkled with salt, and placed on layers in store cellars, lined with ice. One or more large ressels are continually passing to Astracnn from the fisheries, and back again, bringing salt and needful implements, and returning with salt-fish, caviar, 
isinglass, and fish-skins, which latter, in some parts of Russia and Turkey, are made into a sort of leather, or used, when prepared, instead of window-glass.

After the spring fishery of the great sturgeon is over, that of the serruga commences, and lasts about a fortnight. This fish is very abundant, and a single fishing-ressel, or rataga, sometimes takes from fifteen to twenty thousand. The total number taken in one season has been calculated at $1,300,000$, affording the value of $£ 16,000$ in isinglass, and $£ 40,000$ in caviar. Of the common sturgeon, the number captured amounts to 300,000 , yielding in isinglass $£ 6,500$, and in caviar $£ 10,000$.

Iate in the autumn, and during the winter, a second fishery of the great sturgeon is carried on. Large holes are cut in the ice, for the introduction of the apparatus of lines and hooks, and the fish, when caught, are sent off direct, in a frozen state, to Astracan, by means of sledges.

It has been calculated that the spring and winter fisheries of the great sturgeon produce, annually, 103,500 fish, which afford 30,000 pounds of isinglass, and 414,000 pounds of caviar.

The common sturgeon of our seás sometimes 
attains to an enormous size; one recorded by Pennant, which was caught in the Esk, weighed 460 pounds; and in 1502 , a specimen, eight feet long, was caught in a weir below the castle of Shrewsbury, and weighed 190 pounds. The mouth of the sturgeon is destitute of teeth, and it is said to feed principally on mollushs, and various soft substances it may find at the bottom of the water. The under side of the snout is garnished with four barbules or feelers.

Second order: Gills FIXED.

Various specimens of the shark tribe are constant tenants of our seas, and nther species are either accidental or regular visitors to our coasts. Some species of this ferocious group produce their joung alive ; others produce eggs, if they may be so called, or rather horny cases, of an oblong figure and compressed, in which the young fish is inclosed. These cases, when empty, are thrown very commonly on our shores; from each angle long curling appendages or filaments project, at least in the eggs of most, as, for example, the small spotted sea-dog (Scyllium canicula.) They are lnown as sea-purses, mermaids' purses, etc. By means of these filaments, or tendrils, they become attached to sea-reeds; and a small linear fissure, near each end, allows the admission of 
THE SPOTTED DOG-FISII AND WHITE SHARK. 179

water to the inclosed fish, which ultimately escapes by an aperture at one end, which is closed till the fish opens it.

The small spotted dog-fish (Scyllium canicula) and the large spotted dog-fish (Syllium catulus) are common on our coast, especially its more southern portions. They usually swim low in the water, and hunt for prey in troops, feeding on fishes and crustacea. Their voracity and their numbers render them very troublesome to the fishermen, for though they are only about two feet in length, they drive shoals of larger and more valuable species from their haunts; and are, besides, often caught on lines intended for a different capture. We have never known the dog-fish sold in England as food, but have seen it in the market of Dieppe.

That dread of the mariner in the tropical seas, the huge and ferocious white shark, (Curcharias vulguris,) is occarionally seen as a wanderer near our coasts, and more frequently in the Mediterranean, especially in the spring and autumn. The horrible loss of life which this shark has so often occasioned to bathers, or to men that have accidentally fallen overboard, its pertinacity in following the ship, its voracity, and its trenendous struggrles when hauled on deck, have been often described, and 
are the theme of many a sailor. Happily it is not a frequent visitor to our coast, nor a longcontinued resident when it appears.

Another species, the blue shark, (Carcharias glaucus), remarkable for the slenderness of its body, inhabits the Mediterrauean, and periodically visits the Cornish coast, to the great injury of the fishermen. Mr. Yarrell quotes the following details, given by Mr. Couch : "The blue shark is migratory, and I have never known it arrive on the coast of Cornwall before the middle of June; but afterwards it becomes so abundant, that I have known eleven taken in one boat, and nine in another in one day. The injury they inflict on the fisherman is great, as they hover about the boats, watch the lines, which they sometimes cut asunder, without any obvious motive, and pursue the fish that are drawn up. This, indeed, often leads to their own destruction; but when their teeth do not deliver them from their difficulty they hare a singular method of proceeding, which is, by rolling the body round, so as to twist the line about them throughout its whole length, and sometimes this is done in such a complicated manner, that I have known a fisherman give up any attempt to unroll it as a hopeless task. To the pilchard drift-net the 
shark is a still more dangerons enemy, and it is common for it to pass in suecession along the whole length of the net, cutting out, as with shears, the fish and the net that holds them, and swallowing both together."

Other true sharks, as the porbeagle, (Lamna commita,) and the Greenland shark, (Scymmus borealis,) so well known to the Greenland fishers as the deadly foe of the whale, are sometimes also to be seen. The latter species is extremely tenacious of life, and its ferocity is dreadful; it attacks the whale, rending out with every snap large masses of the whale's flesh, while the latter lashes the water with agony or vain efforts to drive away his foe. We may here observe a singular circumstance, connected with the sharks of the temperate and warmer latitudes, as the white shark and the blue slark, that they are often seen attended by two or more small fishes, called pilot-fishes, (Naucrates ductor,) between which and themselves a singular friendship subsists ; they have been known to interpose between their friend and the baited hook, and running against his muzzle turn him from it. On the other hand, perhaps, where they see no danger, they will direct him to the bait, and even cling to him as he is hoisted up on deck. 'This singular 
fish will also attend upon vessels during their course, and that for months together, a circumstance known to the ancients, who regarded it a pilot to the doubtful navigator, and held it sacred. This fish much resembles a mackerel, and is transversely banded. It belongs to the mackerel family.

We may now pass to the skates, or rays, of which many species are natives of our coasts. The singular depression of these fish, the winglike expansion of their side-fins, or pectorals, their long and spiny tails, their peaked snout, the position of the eyes and temporal orifices on the top of the head, and of the mouth, nostrils, and gills, orifices on the under surface, render them at once distinct from all other fishes. In there skates, or rays, the internal surface of both the upper and lower jaws are covered with a close array of teeth, like a tesselated pavement; in some species these teeth are flat or rounded, to act as crushers; in others, they are sharp and conical ; and what is singular, the males of some species have the teeth sharp, the females rounded or flat, and the young of both sexes flat teeth. Few fish are more voracious than these tenants of the muddy or sandy bed of the sea ; they feed on crustacea and shell-fish, crushing then with ease; their 
movements are undulatory, or slicing, and performed by flappings, more or less violent, of their wing-like fins, the long slender tail being lashed from side to side. The skates produce their young in horny cases, much resembling those of the dog-fish, but broader in proportion, and with thicker and shorter filaments. They breed in the spring and summer, and are consequently in the best condition during the winter, and the flaky flesh of various parts is then very delicate. The females of the skates, or rays, of most common occurrence, are called by the fishermen maids; as the skate-maid, the thornback-maid, etc.

Of the species most frequently met with, we may notice the long-nosed skate, (Raia chagrinca,) a large species, and at once distinguishable by its long, slender, tapering snout. In the old males the teeth are very sharp, but flat in the females. Besides this, there is the true skate, (Raia batis,) also called the blue or grey skate. In this species both sexes when adult have sharp teeth. It is common on our coast.

A species, termed the sharp-nosed ray, or white skate, (Raia o.rynrlynclues,) is taken in abundance, and great numbers are sold at Plymouth to the French fishermen for their 
markets during Lent, as it is in high estiniatiol: as an article of food. Its nose is not so much elongated as it is sharp and pointed. The male has sharp teeth, and the skin of the upper surface is spiny.

The homelyn, or spotted ray, (Raia maculata,) is another common species on our coast, and is to be seen in considerable abundance in the London markets. The upper surface is variously spotted.

The thornback (Raia clavata) is also among the most frequent species in our seas, and is taken in great numbers for the markets, where the female is sold as the maid. This species, like the rays in general, is in perfection in winter, but is chiefly taken during the spring, when it leaves the deep sea for the shallower parts in order to deposit its roe. Its fins are very ample, and the upper surface is studded with recurved conical spines. The teeth of the two sexes differ very decidedly. Like the rest of its tribe, this species preys on crustacea, shelled mollusks, soles, the sand-lance, and other ground fish. Some other species of this group are classed among British fishes, but they are rare.

Among the cartilaginous fishes with fixed gills are to be placed those eel-like slimy fishes, 
termed lampreys and lamperns, which form a distinct family (Petromyzidce.) These singular creatures have the lips thick, flexible, and adapted for forming a circular sucker continued around the mouth. The mouth is also circular, and armed with hard tooth-like processes; it is usually concealed by the lips, which cover it when not acting as a sucker. On each side of the neck are seven branchial orifices, opening into branchial cells. The respiratory apparatus of the lamprey engaged the attention of sir E. Home, whose observations were published in the Phil. Trans. 1815, p. 257 , etc.; and it would appear that when the lamprey clings to a stone, by means of its sucking mouth, that the water is received in through the orifices on one side, traverses the internal apparatus, and is discharged from the orifices of the opposite side, a regular succession of currents being maintained.* The hinder caudal portion of the body only is furnished with a continuous fin above and below.

The lamprey, or sea lamprey, (Petromyzon marimus, is widely spread in the seas of Europe and America. It exists in the Mediterranean, as well as in the colder latitudes, and is every-

* See professor Owen's remarks in the Catalogue of the Mus. R. Coll. S. 
where migratory in its habits, ascending the rivers in the spring or summer, according to the advance of the warmer season in their countries. Formerly great numbers worked their way up the Thames to a considerable distance, in order to deposit their roe, but few are now taken. In the Severn, there is a periodical influx of these fishes in considerable numbers, during the months of April and IIay, and also in various rivers which open into the sea, along our southern coast. Many of the Scottish rivers are also visited, but not until summer has set in. They remain in the fresh water about two months, making furrows in the bed, not by boring like the salmon, but by fixing their sucker upon the stones, and removing them from their places, and at this work they assiduously labour. Into these furrows the eggs are deposited, and covered up. The progressive motion of the lamprey in the water is undulatory, like that of an eel, but from time to time it seeks to moor itself to any fixed object that offers, and then darts again onwards. With regard to its food, soft animal substances, and even fish, constitute its nutriment. It fixes on its prey like a leech, and rasps away with its hard teeth till it deeply penetrates. When full-grown, this species 
attains to the length of twenty-five or twentysix inches.

The lamprey has from early times been regarded a delicacy for the table; the potted lampreys of Worcester are celebrated. Henry r., surnamed the Beauclerk, who, as Rapin says, was exceedingly regular in his diet, and "never known to be guilty of any excess in eating or drinking," excepting on the occasion which fatally terminated, brought on his illness, as it is said, by partaking too inmoderately of a dish of lampreys, a fish of which he was very fond.

The colour of the sea-lamprey is olive-brown, marbled with a dark green and dusky brown.

There is a smaller species, termed the river lamprey; or lampern, (Petromyzon fluviatilis,) about twelve or fourteen inches in length, of a bluish colour above, passing into white beneath, which is a permanent resident in many of our rivers, and those of Scotland and Ireland. Formerly this fish was taken in enormous quantities in the Thames, as many as one million or twelve hundred thousand having been captured in a single year. Numbers were sold to the Dutch fishermen as bait; Mr. Yarrell says, that four liundred thousand have been sold in a single season, at the rate of forty 
shillings per thousand. At present, the lampern is far less plentiful in the Thames than formerly. In the Severn, the Dee, the Morsey, etc., it still abounds.

This species breeds in May, and is in the best condition from October to March, during which period only its fishing is permitted. Cuvier states, that it is common in the fresh waters of the continent. Like the sea-lamprey, the lampern is in repute as a delicacy.

A distinct species of lampern, called the fringe-lipped lampern, (Petromyzon planeri,) is occasionally to be met with in our rivers, and more frequently in those of the continent. It is as thick, but shorter than the preceding species, and has its sucking lip peculiarly broad and fringed.

In the Thames, and various other rivers, and in the streams of the continent, is found a species of lamprey, of very small size, being only fire or six inches long, and as thick as a goose-quill. It is called the pride, or sand-pride, or mud-lamprey, and in French, lamprillon, civelle, and chatonille, (Ammocotes branchialis;) its lip is not circular, but presents the form of a horse-shoe, and does not appear to act as a sucker; its mouth is destitute of true teeth.

This little lamprey lives in the mud, and so 
rarely emerges from its lurking-place that it is not to be discovered without some search; Cuvier says, it has been accused of sucking the gills of fishes, because it has, most probably, been confounded with the Petr. planeri. Ho adds, that it is employed as a bait for hooks. It is for this purpose that the Cornish fishermen use it; it abounds in the smaller streams of that county; in its habits it is very inactive.

Along the consts of Europe, including that of our own island, a singular slender fish, abont twelve inches long, is to be found, which Linnæus regarded as belonging to the class of worms. It is, indeed, one of the lowest in structural organization among the fishes, its vertebral column being merely a soft flexible tube; it has no eyes, its mouth is circular, with eight feelers or barbules, and there is one hooked tooth on the palate, and two rows of tecth are on each side of the tongue. Its skin, which is smooth, is most copiously lubricated with a slimy gelatinous secretion, poured out from two rows of glands, extending along the under surface. The head is blunt, with only one spiracle connected with the interior of the mouth; on each side of the body is an orifice, whence proceeds a membranous tube, leading to the respiratory apparatus on its own side. This singular fish is called the 
myxine, or glutinous hag, (Gastrobranchus ccecus.) It is a cleadly foe to fish, into the bodies of which it enters, in some way not well understood, and devours the whule of the flesh. Nilsson says, that several have been found in the body of a single haddock, which was all eaten away internally. The cod-fishers of Scarborough and Berwick often capture this fish in the bodies of cod or haddock drawn up by their lines, and some believe it enters their munth while they are held by the hook. But Cuvier says, it attacks and pierces the fish; aided, perhaps, by the sense of touch implanted in its feelers, it may have the power of suddenly fixing itself by means of its hooked palatal teeth, and then boring and rasping with its lingual teeth, insinuate itself beneath the skin, and gradually work its way into the very body of its victim. Indeed, on some parts of our eastern coast it is called the borer.

Here terminates our sketch of the fish and fisheries of our British islands-a sketch,indeed, for our limited space will allow no more. Yet we trust that the reader, desirous of some general information on the subject, will not be altegether disappointed. To those who wish to make this portion of zoology a study, Mr. Yarrell's work on British Fishes is indispensable. 
We ought not to conclude, however, without a thankful recognition of that adorable Being who made "the seas and all that is therein." How true it is that "God is love!" Every examination of his works, as the Creator, furnishes illustrations of this fact, and may prepare us to acknowledge with gratitude that pre-eminent exhibition of his kindness, which he made in the gift of an Almighty Saviour. "In this was manifested the love of God toward us, because that God sent his only begotten Son into the world, that we might live through him. Herein is love, not that we loved Gud, but that he loved us, and sent his Son to be the propitiation for our sins," 1 Jolnn iv. 9, 10. The same gracious disposition which was evinced in this gift-a gift which the apostasy of our race had rendered necessary-had been previously displayed in the multiplication of objects adapted to promote man's earthly lrappiness. How wonderfully conducive to our welfure are the qualities which the Creator has imparted to the roaming tenants of the waters ! The amount of nutritious food, agreeable to the palate and diversified in flavour, some adapted for the digestive powers of the robust, and some for the delicate stomach of the invalid, derivable from rivers, lakes, and seas, is incalculable; 
while the convenience of man is promoted by the employment, in useful manufactures, of kinds and parts of fish which are not suitable for food. The contemplative mind may see in all this man's obligations to the Creator and Preserver of the universe. Alas, that we should have rebelled against so much goodness! Alas, that any should be inattentive to the message of reconciliation! Is the reader one who has hitherto preferred distance from God to that communion with hin which is to be enjoyed through the mediation of his Son? Let him hearken to the invitations of mercy, and in the spirit of the repentant prodigal say, "I will arise and go to my father." Let him avail himself without delay of that benign arrangement, by which the renewing influences of the Holy Ghost are imparted to every believer, and guilty outcasts are accepted, through the righteousness of our Lord and Saviour, in a way consistent with the integrity of the Divine character and the supremacy of the Divine law.

RELIQIOUS TRACT SOCIETY: INSTITUTED 1799. 


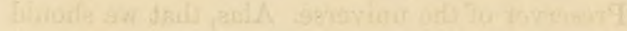

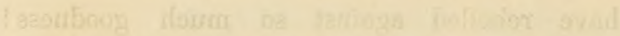

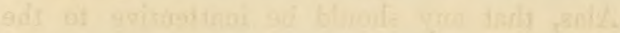

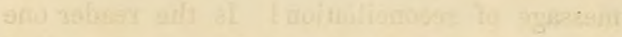

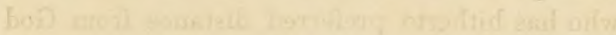

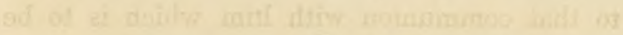

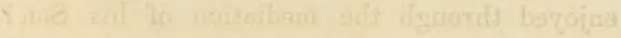

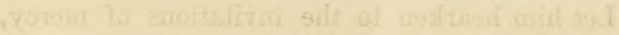

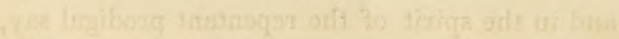

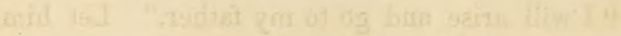

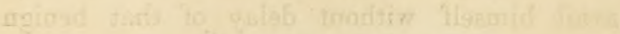

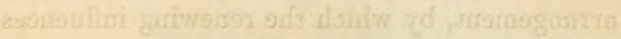

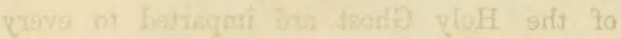

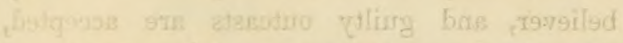

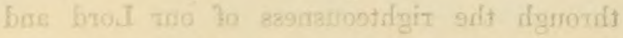

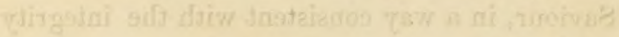

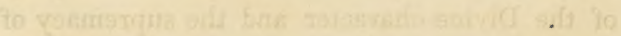

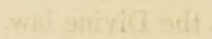





\section{PLEASE DO NOT REMOVE}

CARDS OR SLIPS FROM THIS POCKET

\section{UNIVERSITY OF TORONTO LIBRARY}

QL

617

M3

BioMed
Martin, William Charles Lin naeus

\section{British fish and fisheri}


